\title{
MACRONUTRIENTES, BORO E ZINCO NA CITRONELA DE JAVA: SINTOMAS DE DEFICIÊNCIAS E EFEITOS NA PRODUÇÃO E QUALIDADE DO ÓLEO ESSENCIAL.
}

JOSE ULTAMIO JUNQUEIRA JUNIOR

Enpenitio Agronumo

Orientador: Prof. Dontor Moscyr Corsi

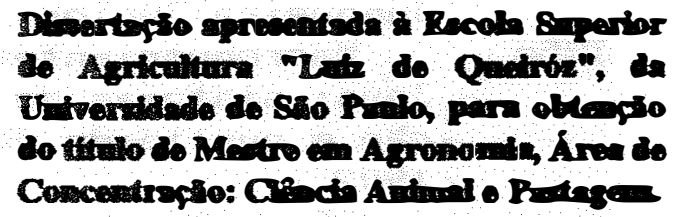

PIRACICABA

Estado de Sxo Paulo - Brasil

Dezembro - 1992 
Ficha catalografica preparada pela Seçăo de Livros da Divisáa de Bibliateca e Documentafäo - FCLQ/USP

Junqueira Junior, Jase Ultimio
Macronutrientes, boro e zinco na citronela de
Java: sintomas de deficiencias e efeitas na prod
că e qualidade do oleo essencial. Firacicaba,
1992.
55p. ilus.
Diss. (Mestre) - ESALQ
Eibliagrafia.
1. Eoro em citronela 2. Citronela - Nutriça 3. Macronutriente em citronela 4. Oleo essencial de citronela 5. Planta aromatica b. Zinco em citronela I. Escola Superior de Agricultura Luiz de Queiroz, Firacicaba

CDD $\quad 633.82$ 


\section{MACRONUTRIENTES, BORO E ZINCO NA CITRONELA DE JA VA: SINTOMAS DE DEFICIÊNCIAS E EFEITOS NA PRODUÇÃO E QUALIDADE DO ÓLEO ESSENCIAL.}

Jose Ultimio Junqueira Junior

Comissåo julgadora: $01 / 02 / 93$

Prof. Dr. Moacyr Corsi

ESALQ/USP

Prof. Dr. Francisco Antonio Monteiro

ESALQ/USP

Prof. Dr. Fernando Romariz Duarte

IAC

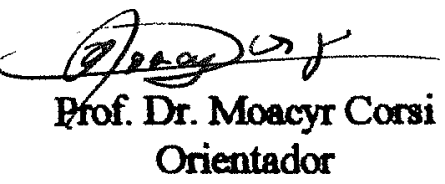


Aos meus pais Norma e José Untímio pelo exemplo de vida e apoio constante,

dedico. 
Agradecimentos:

Gostania de agradecer a todos que direta ou indiretamente auxiliaram na confeccăo deste trabalho, especialmente aos que seguem: Prof. Moacyr Corsi, Prof. Antonio Rogue Dechen, Profa. Marisa A. B. Regitano d'Arce, Prof. Irineu Humberto Pacler, Femando Romariz Duarte, Prof. Francisco A. Monteiro, Penando C. Voiga Neto, Luciano M. Verdade, Martha C. Atves Esteves, A. Casselli Jr., L. M D. Pacheco, Juarez C. Fenreirs, Katia M de Andrade Ferraz, Eliana M. Garcia Sabino, Secção de Plantas Aromáticas do IAC nas pessoas de Odair A. Bovi, Hilda M da Silva Honório, Paula Durante, Cristiano de Moraes, CAPES (Bolsa do Pos-graduapăo), FIRMENICH \& CIA LTDA, Divisåo de Documentaçăo da Biblioteca Central da ESALQ/USP. 


\section{SUMARIO}

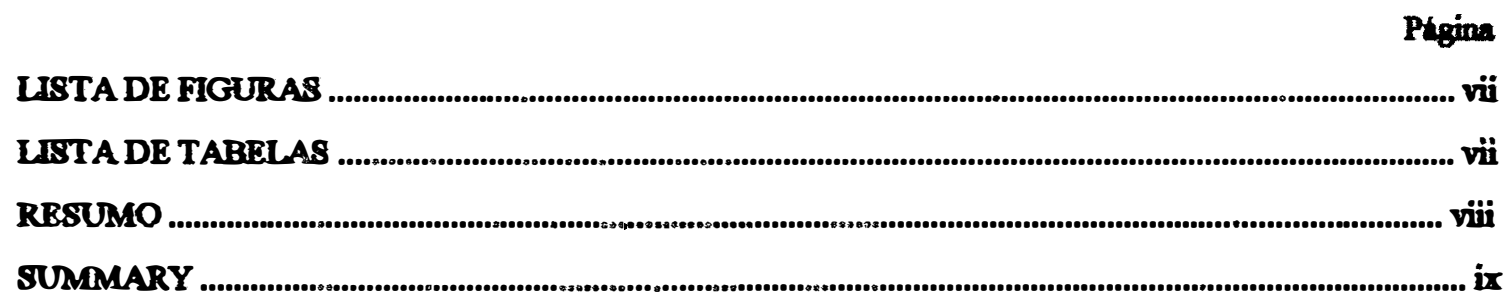

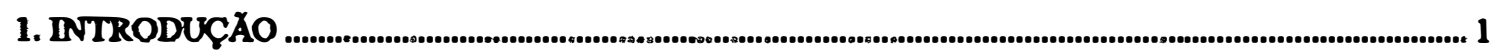

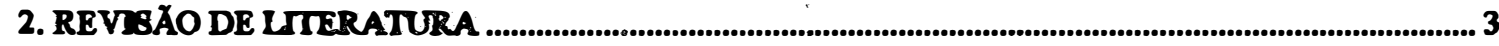

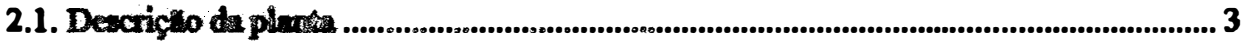

2.2. Uson e mercadob .......................................................................................................................................... 4

2.3. Nutrifle uminerd ........................................................................................................................................ 6

2.3.1. Importancia dos nestrientes ..................................................................................................... 6

2.3.2. Earreglo de matrientes ................................................................................................... 8

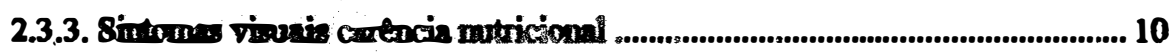

2.3.3.1. Deficilencin de nitrogetio ........................................................................... 11

2.3.3.2. Deficienacia de Dafuro ................................................................................ 12

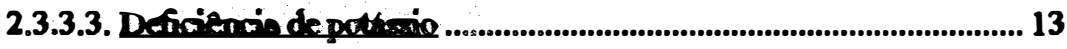

2.3.3.4. Deficiencia de ctlaio ....................................................................................... 14

2.3.3.5. Deficiencia de mantrio .............................................................................. 15

2.3.3.6. Deficientis de canofice ................................................................................... 15

2.3.3.7. Definitariz de boro ........................................................................................ 16

2.3.3.8. Deficitencis de zimco ...................................................................................... 17

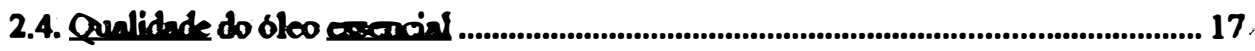

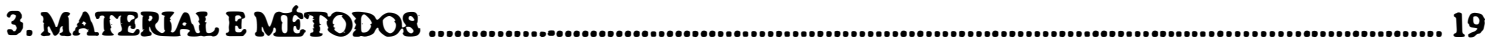

3.1. Local e data ...................................................................................................................................... 19

3.2. Recipieriba e subetrato ...................................................................................................................... 19

3.3. Mudas ................................................................................................................................................... 19

3.4 Soluçbe nitritivas ....................................................................................................... 20

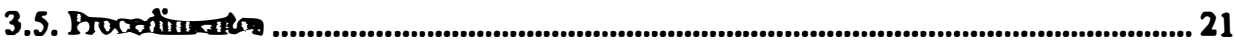

3.6. Corte e detilapso ........................................................................................................... 21

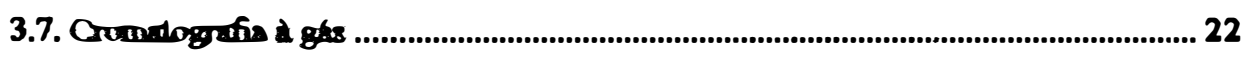

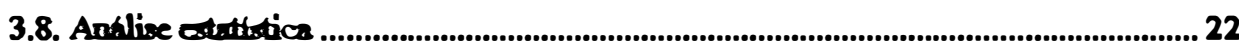




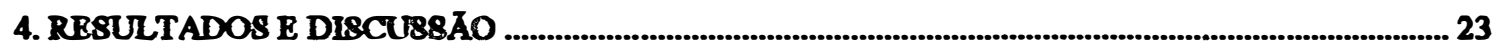

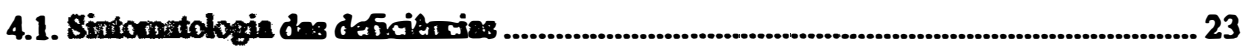

4.1.1. Tretamert to completo ........................................................................................ 23

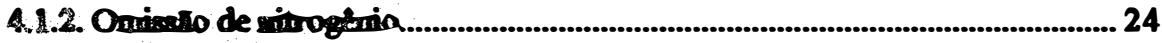

4.13. Omins de forforo

4.1.4. Omiseso de pot ria............................................................................................... 25

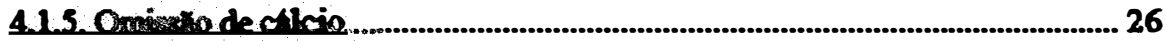

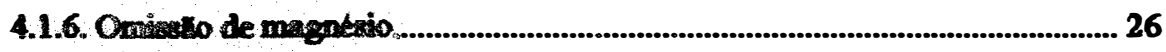

4.1.7. Omiss to de emofie .......................................................................................... 27

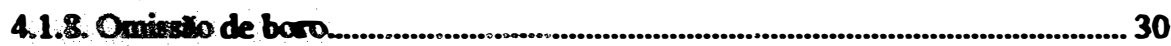

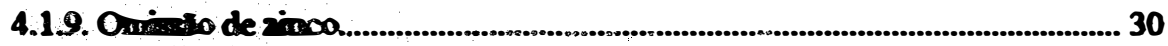

4.2. Produfto de an.turia verde e de bleo ................................................................... 30

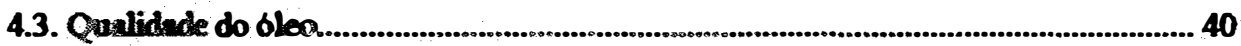

4.3.1 Antlise univariada dos prixcipnis conconentes,

4.3.1.1. Citronela. ............................................................................................ 41

4.3.1.2. Citroneld

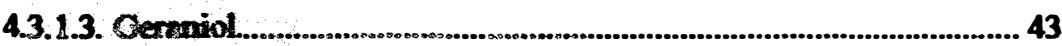

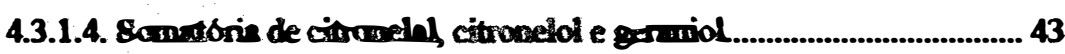

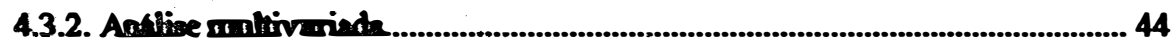

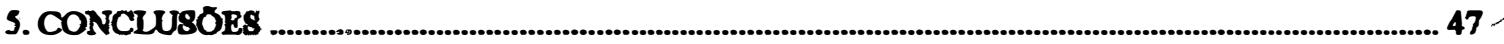

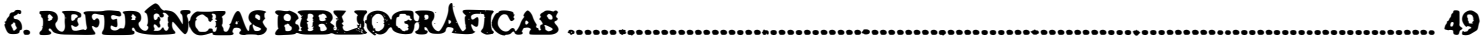

Apentice 1 Produpho: dados e endlise de varilmia ....................................................................................... 54

Apândice 2 Comparielo do bleo: dados e antises .......................................................................................... 58

Apendice 3 Cromitogemas repeseninives de cads tratumento .................................................................61 
1. Derivados do bleo eneencial de citronela ......................................................................................................... 5

2. Fotografies dow tratmento antes do preimeiro corte .................................................................................... 28

3. Detalhes de coloragrao de folhas de plantas deficientes em fosfora, potassio e emxofire ............................... 28

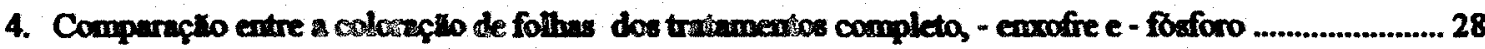

5. Folhn nove de citronela deficiente em bero ............soson..................................................................................... 28

6. Fotografins dos tratamentos antes segando corte ......................................................................................... 29

7. Produçro de materia verde no primeiro corte ..................................................................................................... 31

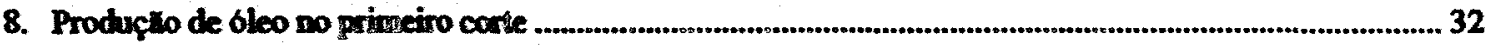

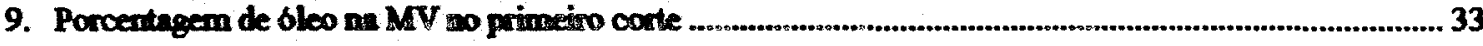

10. Produçuto de mattria verde (MV) no segando carte ...............................................................................................34

11. Produghio de dleo an segundo corte ................nono.non...............................................................................35

12. Poncentugem de oleo m MV no regando conle ..................................................................................... 36

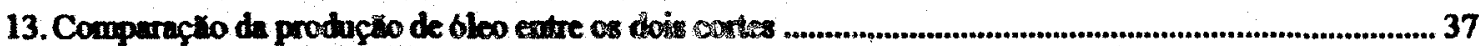

14. Picos identificados nos cromatogrames de sleo de citroneln ....................................................................... 41

15. Grafico des Varikveis Conónicas CAN1 x CAN2 ................................................................................. 45

Lista de tabelas

1. Preparaçlo das soluçbes mutritivas perse cade tratumento ............................................................................. 20

2. Teste bilateral de Dunned de varilvel materia verde no primeiro corte .....................................................31

3. Teste bilateral de Dunnett da varitvel produçto de bleo no primeiro corte ................................................32

4. Teate bilateral de Dunnett da variavel porcentagem de bleo ma MV no primeiro corte ..............................33

5. Teste bilateral de Dunnett de varitvel produçato de MV no segundo corte ................................................. 34

6. Teste bilateral de Dunnett da varidvel produçăo de óleo no segundo corte ..................................................35

7. Teste bilateral de Dumett da varikvel poncentagem de bleo na MV no segando corte ............................... 36

8. Teste bilateral de Dunnett para as medias dos tratamentos da varihvel citronelal ..................................... 42

9. Teste bilateral de Dumett para as médias dos tratamentos da varitvel citronelol ......................................42

10. Teste bilateral de Dunnett para as médins dos tratamentos da varitivel geraniol .........................................43

11. Teste bilateral de Dumett da varitvel citronelal tcitronelol +geramiol ....................................................... 44 


\title{
MACRONUTRIENTES, BORO E ZINCO NA CITRONELA DE JAVA: SINTOMAS DE DEFICIÊNCIAS E EFEITOS NA PRODUÇÃO E QUALIDADE DO ÓLEO ESSENCIAL.
}

\author{
Autor: JOSE ULTMMO JUNQUEIRA JR. \\ Orientador: PROF. DR. MOACYR CORSI
}

\section{RESUMO}

Para que pudessem ser caracterizados os sintomas das deficiências dos macronutrientes, de boro e de zinco na citronela de Java, foi utilizada neste trabalho, a técnica de omissão de cada nutriente da solução autritiva. Deste modo a citronela foi submetida à nove tratamentos: completo, $-\mathrm{N},-\mathrm{P},-\mathrm{K},-\mathrm{Ca},-\mathrm{Mg},-\mathrm{S},-\mathrm{B}$ e $-\mathrm{Zn}$. Além dos sintomas visuais, foram avaliadas a produçåo e a composição do óleo essencial obtido em cada tratamento.

Das plantas cultivadas com omissão de algum nutriente, somente as submetidas ao tratamento $-\mathrm{Zn}$, năo apresentaram sintomas visuais de deficiência nutricional. A produção de bleo foi sensivelmente afetada pelos tratamentos, sendo aqueles com omissăo de $\mathrm{K}$, de $\mathrm{N}$ e de $\mathrm{S}$ os mais prejudicados.

A composição também sofreu alterações, com destaque para a redução dos teores de citronelal e geraniol, nos tratamentos $-\mathrm{K}$ e $-\mathrm{S}$, respectivamente. A subtração de $\mathrm{Mg}$ aumentou a relação citronelal/geraniol e a quantidade de oleo obtida foi ligeiramente superior ao completo, embora as plantas tenham acusado a falta desse nutriente através de sintomas visuais.

Para a avaliação qualitativa foi sugerida uma análise multivariada dos componentes (picos cromatográficos) do óleo essencial. Esta análise, além de outras aplicaçð̌es, parece ser um método bastante promissor na determinação de possiveis deficiências nutricionais em plantas aromáticas. Os componentes P8 e P6 foram, nesta ordem os que mais sensivelmente discriminaram os tratamentos. 


\title{
MACRONUTRIENTS, BORON AND ZINC IN JAVA CITRONELLA: DEFICIENCIES SYMPTOMS AND EFECTS ON YIELD AND ESSENTIAL OIL QUALITY.
}

\author{
Author : JOSE ULIMIO JUNQUEIRA JR. \\ Adviser: Dr. MOACYR CORSI
}

SUMMARY

In order to characterize the visual symptoms of macromutrients, boron and zinc deficiencies in the Java citronella, the technique of omition of each nutrient from the nutritive solution was used. Nine treatments were imposed to citronella: complete, $-\mathrm{N},-\mathrm{P},-\mathrm{K},-\mathrm{Ca},-\mathrm{Mg},-\mathrm{S},-\mathrm{B}$ and $-\mathrm{Zn}$. Besides the visual symptoms, yield and essential oil composition were evaluated.

Except for the $-\mathrm{Zn}$ plants all the others showed the visual symptoms of nutrient deficiency. Oil production was influenced by the treatments, and the $-\mathrm{K},-\mathrm{N}$ and $-S$ were the most affected.

The oil composition was also affected, and decreases in citronelal and geraniol contents were observed in the $-\mathrm{K}$ and $-\mathrm{S}$ treatments, respectively. Plants in the no $\mathrm{Mg}$ treatment, had higher citronelal/geraniol ratio and higher quantity of oil than those in the complete treatment, although visual $\mathrm{Mg}$ deficiency symptoms were observed.

Multivariated analysis of the components (cromatographic peaks) of the essential oil was used for the qualitative evaluation. This analysis, among other applications, seems to be very promissing in the determination of possible nutritional deficiencies in aromatic plants. The components $\mathrm{P} 8$ and $\mathrm{P} 6$ were, in this sequence, those who most sensibly discriminated the treatments. 


\section{INTRODUÇAO}

A citronela é uma planta aromática originaria do Sri Lanka (antigo Ceilao), da qual se extrai um óleo essencial que é utilizado pela indústria de odorizantes desde a metade do século passado, conhecido internacionalmente como " citronella essential oil".

Comercialmente existem dois tipos de oleo de citronela, protuzidos a partir de duas espécies botanicamente distintas: o tipo Java ("Java citronella oil"), oriundo da citronela de Java (Cymbopogon winteriamus Jowitt), tambem denominada "mahapenguiri" (GUENTHER, 1952), extensamente cultivada em regióes da Ásia, América Central e América do Sul; e o tipo Ceilăo ("Ceylon citronella oil"), extraido da citronela do Ceilåo (Cymbopogon nardus Rendle), ou "lenabatu", ate hoje cultivada apenas em Sri Lanka.

A citronela conhecida como tipo Java, segundo GUENTHER (1952), foi levada do Ceilăo para Java por alguns pioneiros da indústria de perfumes, tendo sido introduzida por volta de 1890 . Na Indonesia encontrou condiçóes bastante favoráveis propagando-se rapidamente. Anos mais tarde, os japoneses a levaram para Formosa de onde passaram a abastecer sua demanda. Na América Central, mais precisamente na Guatemala, a introduģăo cocorreu por volta de 1930 estimulada pelo declinio das plantações de banana, devido ao "mal de sigatoka".

Embora atualmente o oleo tipo Java seja considerado de melhor qualidade, sendo industrialmente mais vantajoso, nos primeiros anos, houve dificuldade de penetraçăo deste tipo de oleo no mercado internacional, acostumado com o padrăo 
olfativo da citronela do Ceilăo. Até 1900, praticamente a totalidade do óleo comercializado, era oriundo de citronela do Ceilăo. Esta situaçăo modificou-se gradualmente até que, nos anos 30 , o tipo Java passou a dominar o mercado mundial de oleo de citronela.

A ocupaçăo de Java pelos japoneses, durante a Segunda Guerra, bloqueou a exportaçăo do óleo para o Ocidente. A procuçăo Javanesa foi desestimulada, declinando rapidamente. A falta do óleo de citronela de Java nos mercados norte americano e dos palses aliados estimulou a produçăo na Guatemala, bem como, a introduçăo em outros palses. Desta forma, Honduras, Heiti, Congo Belga e outros, iniciaram a produção desse óleo.

Foi provavelmente nos anos cinquenta, que a citronela chegou ao Brasil. Trazida por imigrantes, a cultura instalou-se ds margens do rio Uruguai na região de Porto Soberbo, norceste do Estado do Rio Grande do Sul, na divisa com a Argentina, onde ainda hoje é produzida a maior parte da citronela brasileira.

Em Porto Soberto, as propriedades săo pequenas e a măo de obra é basicamente familiar. A mecanizaçåo e praticamente inexistente, há pouca utilizaçăo de insumos e a destilaçăo e feita em alambiques bastante rudimentares. Estas caracteristicas de exploração aliadas ao clima frio daquela região conconrem para uma baixa produtividade da cultura o que, eleva o custo de produçăo e dificulta a colocaçăo do oleo no mercado internacional a preço competitivo. Já nos Estados do Sudeste do Brasil, onde o clima é mais propicio à exploração de capins tropicais, a citronela têm demonstrado um bom potencial produtivo, apresentando-se como numa opçăo de diversificaçăo agroindustrial bastante promissora também para pequenos produtores.

Os processos de extraçăo de óleos essenciais de plantas, săo conhecidos e aprimorados à centenas de anos e năo se espera grandes aumentos de rendimento 
advindos de pesquisas nesta área. Estes aumentos no entanto, se mostram ainda possiveis na parte agricola, a medida que se conhece melhor a planta e se estabelece técnicas de manejo mais adequadas para a cultura.

Este trabalho teve como objetivo identificar e caracterizar os sintomas de deficiências de macronutrientes, boro e zinco na citronela, além de verificar a influência da omissåo desses nutrientes na produçăo e qualidade do bleo essencial, se constituindo num passo inicial para futuros estudos sobre nutriçăo desta planta aromática.

\section{REVISAO DE LTTERATURA}

\subsection{Descriç̌o da planta}

Taxonomicamente a citronela de Java (Cymbopogon winterianus Jowitt), pertence à familia Gramineae, a subfamilia Panicoideae, e d tribu Andropogoneae. É uma planta herbacea, perene, estolonifera, que forma touceiras com muitos perfilhos. As folhas são laminares com bainhas invaginantes, såo longas e estreitas. $O$ caule é ereto e nodoso, podendo alcançar $1,5 \mathrm{~m}$ de altura.

A citronela se adapta bem à vários tipos de solo e clima, vegetando abundantemente nas regiőes tropicais. A propagaçăo é feita vegetativamente, atraves de propágulos obtidos pela divisåo da touceira já que, apesar de florescer abundantemente nas condiçōes do Brasil Central, a produçăo de sementes férteis é muito baixa (PINTO et al, 1963). Solos leves e bem drenados favorecem o estabelecimento.

E uma planta do tipo $\mathrm{C}_{4}$ (HERATH \& ORMROD, 1977), apresenta baixo ponto de compensação de $\mathrm{CO}_{2}$, podendo ser considerada como uma graminea tropical, e portanto, com potencial para alcançar altas produções de massa verde em condiçđes satisfatorias de temperatura, luminosidade, agua e nutrientes. 


\subsection{Usos e Mercados}

As folhas desta graminea possuem micro-pelos glandulares (IRUTHAYATHAS \& HERATH, 1982) que sintetizam e armazenam um bleo aromático que pode ser facilmente extraido por destilaçåo com arraste de vapor, sendo este seu principal interesse econômico. $O$ bagaço que sobra desta destilaçăo, pode ser aproveitado diretamente como volumoso para alimentaçăo de ruminantes de baixa exigência nutricional (SUBBA RAO et al, 1984), ou ainda sofrer algum tipo de tratamento para aumento da digestibilidade (ROLZ et al, 1986). A composiçăo do bagaço da citronela segundo os últimos autores a a seguinte: NDF (72.0\%); ADF (42.0\%); lignina (11.1\%); celulose $(28.5 \%)$; hemicelulose $(30.0 \%)$; cinzas $(9.3 \%)$; proteina bruta $(4.5 \%)$; bleo essencial (traços).

O bleo essencial de citronela tem grande utilidade na odorização de sabdes, desinfetantes e ceras. Mascarando odores indesejaveis de certos ingredientes, cede uma nota de frescor a esses produtos (INTERNATIONAL TRADE CENTRE UNCTAD/GATT, 1986). Também usado na fabricaçăo de cremes repelentes de mosquitos, e na composiçăo de alguns sabonetes medicinais.

Por ser especialmente rico em citronelal e geraniol, compostos de ampla utilizaçăo na perfumaria, o óleo de citronela é também, matéria prima para extraçăo desses compostos por fracionamento. O geraniol assim como seus derivados, é empregado em composiçoes florais em perfumaria fina, possuindo fragrancias remanescentes de rosa. O citronelal pode ser transformado em hidroxicitronelal, utilizado para a sintese do l-mentol, importante aromatizante de balas, bebidas, doces, etc (Figura 1) (ROBBNS, 1983). 


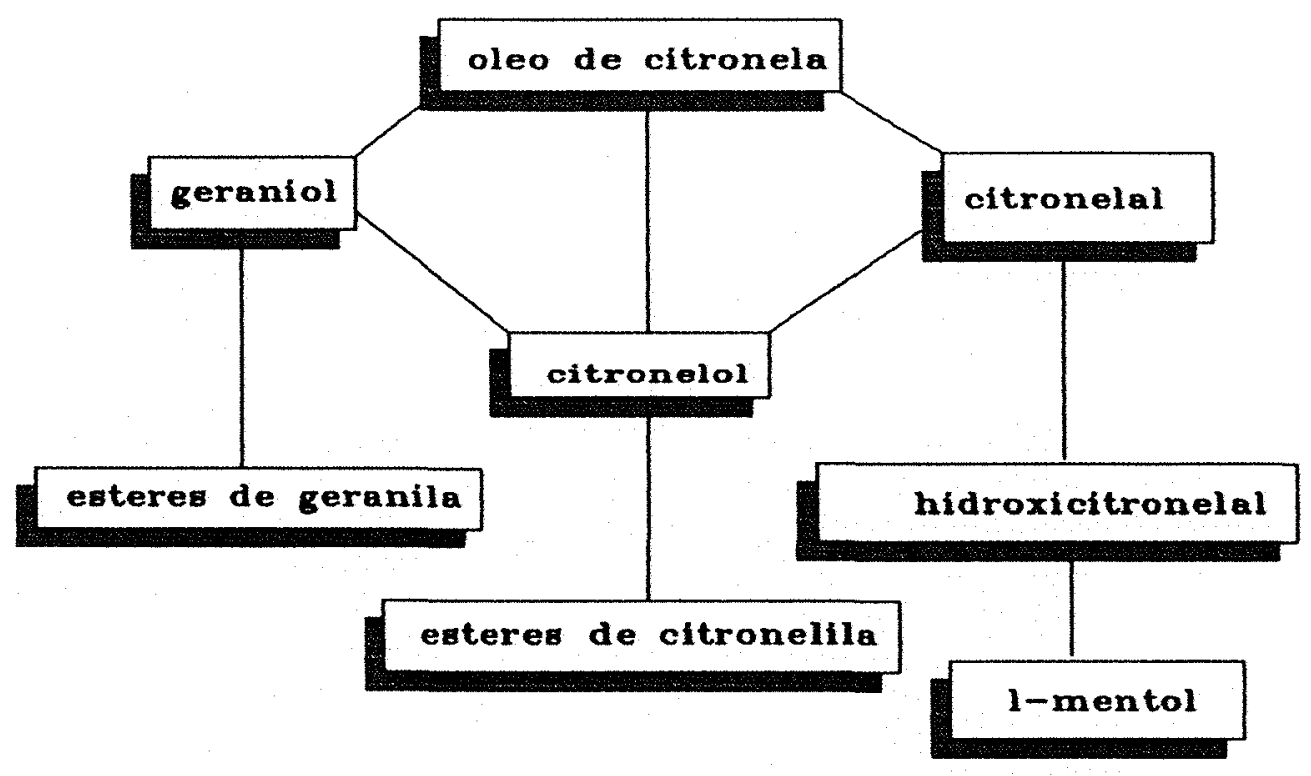

Figura 1. Derivados do bleo essencial de citronela.

A citronela do Ceilão é menos procurada pois seu oleo apresenta uma concentraça de alcoois totais da ordem de 55 a $65 \%$, com 7 a $15 \%$ de citronelal. $\mathrm{Na}$ citronela de Java os alcoois totais normalmente somam mais de $85 \%$, com teores de citronelal em torno de 35\% (GURNTHER, 1952).

O mercado intemacional chega a comercializar entre 2.000 e 2.500 toneladas de bleo de citronela por ano (ROBBINS, 1983). Deste total, a Indonésia é responsavel por 40 a $50 \%$, a China exporta pouco menos que a Indonésia, enquanto Taiwan, Guatemala e Sri Lanka, ficam aproximadamente com $5 \%$ cada. O Brasil responde por $2 \%$ desse mercado (ROBBINS, 1983). Além destes, outros patses são eventuais exportadores, principalmente: Vietnan, Tailandia, India, México, Honduras e Republica Sul Africana.

Dados do último Simposio de Óleos Essenciais realizado no Brasil, apontam que a produgăo brasileira e da ondem de 65 tano, sendo Porto Soberbo (RS), a regiåo de maior produçăo com 70\% deste total (KIEFER, 1986). 
O consumo interno brasileiro de dleo de citronela é bastante significativo, pois várias multinacionais do setor de perfumaria, mantém unidades produtoras no Brasil e embora o pais figure na lista dos paises exportadores, este fluxo em certas ocasiớes têm se invertido. A queda nas aliquotas de importaçăo de geraniol vêm tomando o produto importado econômicamente mais interessante e além disso, o preço internacional é mais estável e a entrega assegurada.

A citronela sofre concorrência de outros óleos essenciais (ROBBINS, 1983), como é o caso do Eucalipto citriodora na obtençăo do citronelal, ou da palmarosa (Cymbopogon martini) na produçăo de geraniol. Há também a concorrência dos compostos sintéticos, obtidos à partir da terebentina, usada para a fabricação de muitos principios aromáticos utilizados em perfumaria.

O Brasil tem condiçres de solo e clima para produzir um óleo de citronela qualitativamente comparável ao dos melhores produtores mundiais. PEYRON (1972) ao analisar algumas amostras de bleos essenciais provenientes do Mato Grosso, ressaltou as excelentes caracteristicas qulmicas, olfativas e de coloraçăo do oleo de citronela oriundo daquela regiăo.

\subsection{Nutriçæo Mineral}

\subsubsection{Importincia dos Nutrientes}

A produção vegetal é resultado da atividade bioquimica das plantas, utilizando energia solar e nutrientes para a formaçăo de compostos orgânicos. As plantas superiores necessitam para o seu desenvolvimento além de $\mathrm{CO}_{2}$ e $\mathrm{H}_{2} \mathrm{O}$, dos nutrientes $\mathrm{N}, \mathrm{P}, \mathrm{K}, \mathrm{Ca}, \mathrm{Mg}, \mathrm{S}, \mathrm{B}, \mathrm{Cl}, \mathrm{Cu}, \mathrm{Fe}, \mathrm{Mn}, \mathrm{Mo}, \mathrm{eZn}$.

Vários săo os exemplos de elementos em compostos vitais, como $\mathrm{N}$ nas proteinas, $\mathrm{P}$ nos ácidos nucleicos, Fe nos citocromos e Mg na clorofila. Alguns outros, 
embora predominem na forma iônica, tem funçðes importantes como é o caso do $\mathrm{K}$ na regulaçăo osmótica e mecanismo estomático (MALAVOLTA, 1979).

A falta, ou mesmo a simples carencia, de determinado nutriente, resulta em prejuizo no desenvolvimento das plantas, podendo haver diminuiçăo da produtividade ou, dependendo da severidade e da época de ocorréncia, acarretar até mesmo morte da planta.

Nas gramineas forrageiras, a baixa disponibilidade de fosforo na época do plantio, pode comprometer seriamente o estabelecimento da pastagem. Os capins gordura (Melinis minutiflora P. de Beauv) e jaragua (Hiparrhenia rufa Stapf) tem sérias dificuldades de estabelecimento em meios com ntveis de fósforo abaixo de $5 \mathrm{ppm}$, enquanto o capim-coloniðo (Panicum maximum Jacq) necessita de $10 \mathrm{ppm}$ no minimo (WERNER \& MATTOS, 1972; WERNER \& HAAG, 1972).

Já o potássio e o nitrogênio săo importantes no estimulo à protuçăo. VICENTE-CHANDLER et al (1964) estudando o uso de altas doses de nitrogennio em gramineas tropicais, relataram que entre estas, há espécies que apresentam capacidade de resposta a niveis de até $1800 \mathrm{Kg}$ de N/ha/ano. SALETTE (1970) demonstrou a importância da adição de potássio no manejo intensivo de capins tropicais, constatando que doses crescentes de nitrogênio não proporcionavam aumentos na produção do capimpangola quando o nivel de potássio era baixo, com a adição do potássio o efeito da adubaçåo nitrogenada se fazia sentir.

O calcário é fundamental para a correça da acidez do solo, potencializando as respostas de $\mathrm{N}, \mathrm{P}$ e $\mathrm{K}$, além de ser fonte de $\mathrm{Ca}$ e $\mathrm{Mg}$ também indispensaveis as plantas.

A citronela, embora nåo seja uma graminea utilizada para pastejo (as plantas năo săo palatáveis aos animais antes da extraçăo do bleo essencial), apresenta 
caracteristicas morfo-fisiologicas muito proximas de gramineas forrageiras tropicais. $O$ gênero Cymbopogon, a que pertencem além da citronela, a palma-rosa (Cymbopogon martini) e o lemongrass (Cymbopogon citratus) popularmente conhecido como "erva cidreira" ou "capim santo", foi desmembrado pela sistemática, do gênero Andropogon (em algumas referências ainda es possivel encontrar a denominaçăo Andropogon nardus Rendle), que apresenta especies sobejamente conhecidas como forrageiras como o capim de gamba (Andropogon gayamus Kunth). Esta proximidade será explorada nesta revisão, já que as gramineas forrageiras foram mais estudadas que as aromáticas.

\subsubsection{Extraç̌̃o de nutrientes}

A intensidade do processo de produçăo vegetal depende da capacidade fotossintética das folhas, do $\mathrm{CO}_{2}$ do ar, da intensidade luminosa, além da umidade, e dos nutrientes fornecidos pelo solo. Sabe-se que o potencial de produçáo de gramineas tropicais bastante elevado, não sendo incomuns produções acima de 50 toneladas de MS/ha/ano (VICENTE-CHANDLER et al., 1964; SILVEIRA et al., 1976). Essa biomassa exportada, é formada as custas de grande quantidade de nutrientes.

HAAG \& DECHEN (1984), apresentando dados de alguns autores, ressaltam a elevada absorçăo de nitrogênio e potássio nas forrageiras $(11,5$ e 20,2 Kg/ton em Andropogon gayanus e 10,7 e $24,6 \mathrm{Kg}$ ton de MS em capim-coloniăo, respectivamente). Concentraç⿸es semelhantes de $\mathrm{N}$ e $\mathrm{K}(10,7$ e 16,6 Kg/ton de MS) tambem foram observadas por BOMMEGOWDA et al (1983), em citronela adubada com $150 \mathrm{Kg}$ de N/corte, com produçăo média de $6 \mathrm{t}$ de MS/corte, independentemente da quantidade de potássio aplicada $\left(42,62\right.$ ou $82 \mathrm{Kg}$ de $\mathrm{K}_{2} \mathrm{O} /$ corte $)$

$\mathrm{Em}$ forrageiras sob pastejo direto, parte desses nutrientes é reciclada através das fezes e urina dos animais, porém no caso de gramineas para corte como as 
utilizadas como capineira, silagen, feno ou mesmo para extraçăo de bleo, os nutrientes passam a ser exportados de maneira intensa. Neste caso, a năo reposiçăo desses nutrientes, resultara em deficiências nutricionais com consequente reduçăo das futuras produçoses (FARIA, 1986).

A citronela, costumeiramente, é explorada por vários anos sem que haja uma preocupaçåa, por parte do proctutor de bleo, com a reposiçăo dos nutrientes. Nem mesmo o bagaço năo utilizado como combustivel na caldeira, retoma da destilaria ds áreas de cultivo como sugerido por DONALISIO (1985). Este procedimento, comum a maioria das áreas produtoras de citronela no Brasil, pode explicar em parte, a baixa produtividade da citronela brasileira (em média, menos de $100 \mathrm{Kg}$ de oleo/ha/ano), bastante abaixo do potencial da cultura que, em trabalhos de autores indianos (SINGH et al, 1983; PRAKASA et al, 1984; MUNSI \& MUKHERJEE, 1986), chega a produzir 250 ate $400 \mathrm{Kg}$ de oleo/ha/ano.

Apesar da baixa absorçăo de nutrientes na fase de implantaçăo da cultura (26,6 $\mathrm{Kg}$ de $\mathrm{N} / \mathrm{ha}$ e $18,5 \mathrm{Kg}$ de $\mathrm{K} / \mathrm{ha}$ ate 150 dias) segundo os dados de PRAKASA \& GANESH (1986), em cultivos explorados mais intensivamente, a quantidade de nutrientes exportada atraves das folhas da citronela é elevada. BOMMEGOWDA et al (1983) considerando um periodo experimental de 25,5 meses, quando foram efetuados 5 cortes, obtiveram uma extração total de $313,1 \mathrm{Kg}$ de $\mathrm{N} / \mathrm{ha}$ e $532,1 \mathrm{Kg}$ de $\mathrm{K}_{2} \mathrm{O} / \mathrm{ha}$ quando adubaram a citronela com $150 \mathrm{Kg}$ de $\mathrm{N} /$ corte. Com metade da dose de $\mathrm{N}$ (75 kg/corte), a extraçăo foi de 201,1 e $356,2 \mathrm{Kg} /$ ha de nitrogênio e potássio respectivamente. Os niveis de adubação potássica ( 42 a $82 \mathrm{Kg}$ de $\mathrm{K}_{2} \mathrm{O} / \mathrm{ha} /$ corte) não tiveram influência significativa $(P>0,05)$ sobre a extraçåo dos nutrientes estudados, e a interaçăo entre $\mathrm{K}$ e $\mathrm{N}$ tambem năo foi significativa a este nivel de significância. 
Aplicaçðes de quantidades adequadas de fertilizantes foram consideradas como o fator mais importante para aumento de produção de massa verde na citronela (SINGH et al, 1983), Em um solo com pH 6,5 contendo $31 \mathrm{Kg}$ de fósforo e $341 \mathrm{Kg}$ de potássio dispontveis por hectare, os autores obtiveram produções máximas (aproximadamente $42,4 \mathrm{t}$ de matéria verde/ha/ano e cerca de $300 \mathrm{Kg}$ de bleo) com uma adubação anual de $120 \mathrm{Kg}$ de $\mathrm{Ne} 80 \mathrm{Kg}$ de $\mathrm{P}_{2} \mathrm{O}_{5}$ /ha. $\mathrm{O}$ fornecimento de $40 \mathrm{Kg}$ de $\mathrm{K}_{2} \mathrm{O}$ não alterou significativamente $(P>0,05)$ a produçăo em relaçăo ao controle sem potássio.

BOMMEGOWDA et al (1980) alertaram para o fato de que o incremento de produçăo de óleo devido à adubaçăo nitrogenada, resultado do aumento do número de folhas produzidas, ja que, a aplicaçăo de nitrogênio demonstrou influenciar negativamente a densidade de glandulas olefferas nas folhas de citronela, reduzindo a percentagem de óleo na matéria verde.

\subsubsection{Sintomas visuais de carencia nutricional}

$\mathrm{Na}$ insuficiência de um dos nutrientes necessários ao desenvolvimento (N, P, K, Ca, Mg, S, B, Cu, Cl, Fe, Mn, Mo e Zn), o metabolismo das plantas sofre alteraçôes que podem se traduzir em sintomas visuais espectficos. Esta insuficiência pode ocorrer por varios fatores, desde a simples falta do nutriente no solo, até uma indisponibilidade temporaria, ou mesmo um desbalanço entre a capacidade de extraçăo e o ritmo de utilização.

A identificaçăo da carência de um nutriente através de sintomas visuais, pode ser bastante útil para correçáo de desbalanços nutricionais antes que a produçåo seja seriamente comprometida. Além disso, evita desperdicios ou mesmo induçăo de outras deficiências ou toxidez, atraves de aplicaçð̄es desnecessárias de nutrientes. 
MALWATKAR et al (1984), descreveram a ocorrência de alguns sintomas como bronzeamento, amarelecimento e enrugamento de folhas de citronela, porem não conseguiram isolar a causa desta anormalidade que, segundo eles, se devia provavelmente, a um desbalanço nutricional ou deficiência de algum micronutriente (possivelmente $\mathrm{Fe}, \mathrm{Zn}, \mathrm{Mn}$ ou $\mathrm{Cu}$ ). Apesar da causa incerta, as folhas que apresentavam este tipo de anormalidade produziam um oleo que continha teores de aldeidos totais (expressos como citronelal) ate $\mathbf{4 0 \%}$ mais baixos que os de folhas normais, depreciando a qualidade do produto. Segundo os autores, a aplicaçăo de $\mathrm{MgSO}_{4}$ e uréia diminuiu a ocorrência deste sintoma.

GUPTA et all citado por BOMMEGOWDA et al (1980), ainda que desconhecendo a causa, resolveu o problema de clorose internerval em citronela cultivada em solo com pH 8 a 8,5, aplicando uma mistura de micronutrientes $(0,2 \%$ de $\mathrm{Zn}, 0,4 \%$ de $\mathrm{Mn}, 0,6 \%$ de $\mathrm{Fe}$ e $1 \%$ de $\mathrm{Cu}$ ).

\subsubsection{Deficiência de nitrogênio.}

Vários autores relataram a importância do nitrogênio para a citronela, revelando interaçðes importantes quanto a: cultivares (SINGH et al., 1980); frequência de corte (MUNSI \& MUKHERJEE, 1986); niveis de adubaçăo e retomo de investimento (BOMMEGOWDA et al., 1981); extração de nutrientes (BOMMEGOWDA et al, 1983) e forma do adubo (PRAKASA et al., 1983; PRAKASA et al., 1984).

Normalmente em ensaios de subtração de nutrientes com gramineas, as plantas submetidas a falta de nitrogênio são as primeiras a manifestar sintomas.

1GUPTA, R.; Saini, A. D.; Pande, P. C.. Possible causes of chlorosis in Java citronella crop. Proceedtage of the All Co-ordinated Improvement Project on Medictnal and Aromatic Plamts. First Workshop, p. 175-9. Bangalore, 1973. 
WERNER \& HAAG (1972) verificaram que o capim-colonilo com oito dias após a supressão de $\mathrm{N}$, já apresentava um desenvolvimento visivelmente menor que o completo, com amarelecimento e secamento das folhas mais velhas, havendo drastica diminuiçăo no perfilhamento e na elongaçăo dos colmos. WERNER (1971) destacou o avermelhamento mais pronunciado das folhas e a diminuiçăo do vigor e da altura dos perfilhos do capim-jaraguá deficiente em nitrogénio.

HAAG et al (1965), também utilizando a técnica de subtraçăo de nutrientes, observaram que além da clorose intensa, houve paralizaçalo do crescimento do capim-elefante (Pennisetum purpureum Schum), submetido a deficiência de N. As plantas segundo os autores, não entouceiraram e nem formaram inflorescência.

Para a cana de açúcar cultivada em solução nutritiva, a omissåo de nitrogênio provocou além da diminuiçăo geral do vigor da planta, a oconéncia de folhas menores e mais rigidas que o normal (HAAG, 1965). $O$ amarelecimento das folhas velhas seguido de secamento, sintoma de caréncia comum à várias gramineas, foi descrito pelo autor como sendo resultado da fragmentaça e do desaparecimento dos cloroplastos em plantas submetidas à restriçăo de nitrogênio.

\subsubsection{Deficiencia de fósforo}

A adiçăo de $40 \mathrm{Kg}$ de $\mathrm{P}_{2} \mathrm{O}_{5} \mathrm{ha}$ no plantio da citronela em solo considerado de mediana disponibilidade neste elemento, aumentou consideravelmente a produçåo de matéria verde (MV) e de bleo, sem alterar a percentagem de bleo na MV (SINGH et al, 1983). O aumento da dose para $80 \mathrm{Kg} / \mathrm{ha}$ nåo alterou significativamente $(\mathrm{P}>0,05)$ nenhum dos parâmetros estudados. 
Apesar da sua quase imobilidade no solo, o fósforo na planta é, assim como o nitrogénio, de fácil translocaçăo. Os sintomas de deficiência ocorrem inicialmente nas folhas velhas e em muitas gramineas provocam mudança na coloraça.

HAAG et al (1965), descreveram a presença de laivos arroxeados nas folhas velhas do capim-elefante deficiente em fósforo, tendência descrita também por WERNER (1971) para o capim- jaragua na supressåo de fósforo.

No capim-coloniăo, além de alteraçăo na cor, a deficiência de fósforo causa reduçăo drástica no perfilhamento e no desenvolvimento geral das plantas, sintomas comuns, tambem ao capim-jaragua (WERNER, 1971). A cana-de-açúcar com caréncia de fósforo apresenta secamento e retorcimento nas pontas das folhas velhas (HAAG, 1965).

\subsubsection{Deficiância de potássio}

Na citronela, mais importante que a quantidade de adubo potássico aplicada, parece ser a manutençăo de um nivel adequado desse nutriente no solo. SINGH et al (1990), encontraram melhores resultados quanto a produçăo de massa verde e bleo, com aplicaçăo de apenas $41,5 \mathrm{Kg}$ de $\mathrm{K}$ /ha em 4 vezes (plantio e três cortes) do que quando aplicaram o dobro desta quantidade, em uma única dose (plantio).

Segundo WERNER (1984), a carência de potassio desencadeia certos sintomas nas gramineas que ao se observar uma pastagem atingida por essa deficiência, tem-se a impressåo desta ter sido "sapecada" pelo fogo. Tal aspecto é causado pelo secamento à partir das extremidades e margens das folhas mais velhas e pela coloraçăo amarelo-alaranjada das folhas médias, como ocorre no capim-elefante e no coloniåo (HAAG et al, 1965; WERNER, 1971). Para estas duas forrageiras os autores ainda 
constataram: diminuiçăo do perfilhamento e desenvolvimento aquem do normal com recuçăo do diametro dos colmos em relaçăo às plantas sadias.

O capim-jaraguá submetido à caréncia de $\mathrm{K}$, apresenta desenvolvimento geral e perfilhamento semelhantes a testemunha, ocorrendo apenas um amarelescimento intercalado de estrias longitudinais marrons nas folhas médias. A medida que as folhas văo ficando mais velhas, a coloraçăo marrom passa a predominar e, mais tarde, ocorre o secamento que se inicia pela ponta e bordos das folhas (WERNER 1971).

As folhas velhas da cana-de-açúcar submetida à carência de potássio, săo as primeiras a manifestar sintomas, principalmente um secamento que evolui das extremidades e margens para o centro do limbo (HAAG, 1965). Essas folhas adquirem uma cor amarelo palido, ha o aparecimento de pequenas e esparsas manchas avermelhadas que vão aumentando gradativamente em número e tamanho.

\subsubsection{Defíciência de chlcio}

Algumas gramineas submetidas a tratamento de omissăo de Ca nem sempre apresentam sintomas visuais nitidos. HAAG et al (1965) nåo conseguiram caracterizar os sintomas de deficiência de cálcio em capim-elefante. Tanto o crescimento quanto o perfilhamento foram normais, segundo os autores.

O capim-coloniăo na ausência de $\mathrm{Ca}$ apresentou-se com coloração verde palido-amarelada, e desenvolvimento reduzido em relaçăo ds plantas normais, sintomas que foram percebidos quinze dias após o inicio do tratamento (WERNER \& HAAG, 1972). Além da coloraçăo alterada, as folhas apresentaram secamento das pontas. No capim-jaragua ocorreu murchamento das pontas das folhas novas, nas epocas de calor mais intenso. 


\subsubsection{Deficiência de magnésio}

Assim como no caso do cálcio, HAAG et al (1965) nåo obtiveram sintomas da deficiência de $\mathrm{Mg}$ em capim-elefante quando suprimiram este elemento da soluçăo nutritiva. De modo análogo, WERNER (1971) também não conseguiu sintomas para o capim-jaraguá deficiente em $\mathrm{Mg}$.

Para o capim-coloniåo, os sintomas foram notados tardiamente e se caracterizaram por uma coloraçăo verde-amarelada, com ocorrência de estrias longitudinais rugosas nas folhas velhas e medias (WERNER, 1971). O autor ressaltou ter sido esta, a última deficiência a manifestar sintomas e mesmo assim, pouco nitidos. As plantas deficientes apresentavam desenvolvimento comparavel ao tratamento completo.

A caréncia de magnésio na cana-de-açúcar, năo provocou alterações no aspecto geral das plantas, que se diferenciaram apenas por sintomas foliares (HAAG, 1965). Nas folhas velhas, apareceram manchas clonóticas isoladas, que a medida que cresceram, se fundiram e adquiriram uma coloraçăo avermelhada. $O$ ápice foliar dessecou, assim como as margens das folhas.

\subsubsection{Deficiencia de enxofre}

Os sintomas de deficiência de enxofre aparecem nas follhas novas de capim-elefante (HAAG et al, 1965); estas folhas perdem a côr verde normal e adquirem coloração verde citrina. Esta caracteristica tambem foi descrita por HAAG (1965), para cana-de-açúcar deficiente em enxofre. $O$ autor descreve que, com o progredir da carencia, aparecem manchas ligeiramente cloroticas, dispostas em linha, que posteriormente, adquirem a cor púrpura. As folhas velhas permanecem com a cor verde original. 
WERNER (1971) não obteve sintomas de deficiência de S para o capim-jaraguá. O capim-coloniăo deficiente em enxofre apresenta ligeira rectuça no crescimento, coloração verde palido nas folhas novas e amarelecimento das folhas velhas (HAAG \& DECHEN, 1984).

\subsubsection{Defíciencia de boro}

Embora as caréncias de micronutrientes nem sempre sejam facilmente percebidas ou reconhecidas, aplicaçðes desses elementos em plantas aparentemente sadias, em alguns casos resultam em aumentos de produçăo, demonstrando aquilo que se conhece por "fome escondida". CHATTERJEE et al (1984), testando a aplicą̧ăo foliar em citronela de alguns nutrientes $(\mathrm{Zn}, \mathrm{Mg}, \mathrm{Mn}, \mathrm{Fe}, \mathrm{B}, \mathrm{Mo})$ em três diferentes concentraçðes $(1,10$ e $50 \mathrm{mg} / \mathrm{l})$, ressaltaram que o melhor resultado dentre os tratamentos, foi a aplicação de $\mathrm{B}$ na forma de ácido bórico $\left(\mathrm{H}_{3} \mathrm{BO}_{3}\right)$ na concentração 10 $\mathrm{mg} / 1$.

SINGH et al (1976) também alcançaram aumento de produtividade de oleo com a aplicaçăo foliar de $50 \mathrm{ppm}$ de $\mathrm{B}$, concluindo que, apesar de năo ter sido estatisticamente significativo ( $P>0,05)$, houve elevaçăo na percentagem de óleo em todos os tratamentos com adição de boro.

Os sintomas de deficiência de $\mathrm{B}$, devido à baixa mobilidade deste elemento na maioria das plantas, costumam ocorrer nas folhas novas e meristemas. Em gramineas forrageiras, esta deficiência, assim como a da maioria dos micronutrientes, dificilmente é relatada. Quanto a esse fato WERNER (1984) enfatizou que enquanto não se suprirem as pastagens com macronutrientes cujas deficiências são mais agudas, não obter-se-ão resultados positivos com aplicação de micronutrientes. 


\subsubsection{Deficiência de zinco}

A deficiência de zinco tem ocorrido com certa frequência em solos do cerrado brasileiro. A aplicaçåo deste micronutriente em muitos casos, é considerada indispensavel para obtençăo de produçőes satisfatórias das gramineas produtoras de gråos (milho, arroz, sorgo etc.). Para estas areas WERNER (1984), recomendou a aplicaçăo de $10 \mathrm{Kg}$ de sulfato de zinco, adicionado à adubaçăo fosfatada, no plantio da graminea forrageira.

Na citronela, BOMMEGOWDA et al (1980), encontraram pequenos aumentos de produçăo tanto de MV (22,5 para 23,5 tha/corte) como de bleo (148 para $154 \mathrm{Kg} / \mathrm{ha}$ corte) quando aplicaram $10 \mathrm{Kg}$ de $\mathrm{Zn} / \mathrm{ha} /$ corte, num cultivo sobre solo com pH 7,0 contendo 2,5 ppm de Zn e sendo adubada com 150,33 e $42 \mathrm{Kg} / \mathrm{ha}$ corte de $\mathrm{N}$, $\mathrm{P}_{2} \mathrm{O}_{5}$ e $\mathrm{K}_{2} \mathrm{O}$, respectivamente. Já CHATTERJEE et al, (1984) constataram que a aplicação isolada de $\mathrm{Zn}$ na forma de $\mathrm{ZnCl}_{2}$ via foliar, foi prejudicial ao crescimento e a produçăo de óleo para todas as concentraçơes estudadas (1, 10 e $50 \mathrm{mg} / \mathrm{l})$. Quando aplicado em combinaçăo com Mg na concentraçăo $10 \mathrm{mg} / \mathrm{l}$ houve aumento de $20 \% \mathrm{na}$ produça de óleo. Os autores năo apresentaram os ntveis de nutrientes no solo da área utilizada para o experimento.

\subsection{Qualidade do oleo essencial.}

Analfticamente, a qualidade de um oleo essencial é avaliada pela sua composição. Álcoois, aldełdos, terpenos e outros componentes, săo medidos através de analises quimicas, espectométricas ou cromatograficas, para serem comparados com padrôes conhecidos. Estas análises são particularmente importantes quando o bleo tem como destino o fracionamento, ou seja a obtençăo de um ou mais componentes que naturalmente existam em maior quantidade. Segundo a ISO (International Organization 
for Standardization) o oleo essencial de citronela tipo Java, resultante da destilaça a vapor das folhas de Cymbopogon winterianus deve possuir as seguintes caracteristicas Densidade relativa $20 / 20^{\circ}$ C: 0,880 até 0,895 ; tndice de Refraçăo: 1,4660 até 1,4730 ; Rotaçăo Ótica: $-5^{\circ}$ até $0^{\circ}$; Solubilidade em etanol $80 \%$ (v/v) a $20^{\circ}$ C: 1 volume em 2 volumes; Compostos acetiláveis: minimo de 85\%; Compostos carbonilicos: minimo de $35 \%$.

Na analise para fins comerciais, o chamado teor de geraniol é determinado através de acetilação. Porém nas condiç̋̃es em que é efetuada, não só o geraniol, más outros alcoois como o citronelol, o nerol, o borneol, o até mesmo o citronelal (um aldeido), são afetados pela acetilação e computados como "geraniol total" (GUENTHER, 1952). A concentraçăo de citronelal é obtida atraves do método da hidroxilamina (GUENTHER, 1952) e o valor obtido corresponde não so ao conteúdo de citronelal, mas encerra pequenas quantidades de outros compostos carbontlicos.

Estes critérios, embora mundialmente aceitos, ainda podem ser insuficientes para garantir a aceitabilidade do oleo, pois nas grandes intústrias do setor, um bleo essencial ou qualquer substância aromática para ser utilizada, precisa ter sido aprovada pelo perfumista apos análise sensorial.

Alguns autores já demostraram que a citronela apresenta variaçŏes na qualidade do oleo em relaçăo à cultivares (WIJESEKERA et al, 1973), maturidade da planta (SINGH et al, 1979), temperatura (HERATH et al, 1979), epoca do corte (PRAKASA et al, 1985; MALWATKAR et al, 1984). GUENTHER, (1952) afirmou ainda que, a altitude, o tipo de solo, a secagem no campo e mesmo o tipo de destilaçăo também influem na qualidade do óleo.

Embora algum desses fatores possa indiretamente estar ligado ao "status" nutricional da planta, a maioria dos trabalhos publicados até o momento, nåo detectou 
influência significativa da aplicaçăo de fertilizantes sobre a composição do óleo essencial, mesmo nos casos em que a produção é afetada (PRAKASA et al, 1985; MUNSI \& MUKHERJEE, 1986; SINGH et al, 1976; SINGH et al, 1990).

\section{MATERIAL E METODOS}

\subsection{Data e local}

O experimento foi conduzido em casa de vegetaça do Setor de Nutrição Mineral de Plantas do Departamento de Quimica da Escola Superior de Agricultura "Luiz de Queiroz". O plantio foi feito em 20 de janeiro de 1989, e os tratamentos iniciados 25 dias após. Os cortes foram efetuados em 15/04/89 15/06/89, a alambicagem das folhas foi feita no laboratório de oleos do Departamento de Tecnologia de Alimentos da Escola Superior de Agricultura "Luiz de Queiroz" em Piracicaba, SP.

\subsection{Recipientes e substrato}

Foram utilizados baldes plásticos cilindricos de 3 litros de capacidade. $\mathrm{Na}$ porçăo inferior de cada balde foi feito um orificio, no qual foram acoplados, uma rolha e uma mangueira plastica que servia para escoar a soluçăo. Para reter o substrato foi colocada internamente, junto ao orificio, uma pequena tela plástica. Como reservatório foram utilizados vidros ambar com capacidade de 1 litro. O substrato utilizado foi sllica lavada.

\subsection{Mudas}

Foram escolhidos, para cada vaso, 5 perfilhos maduros de plantas adultas que aposs serem fixados na sllica, sofreram um corte a $10 \mathrm{~cm}$ de altura, eliminando-se assim, as folhas para diminuir a transpiraçăo. Cada vaso foi irrigado diariamente com 
soluçăo completa segundo SARRUGE (1975), diluida na proporçăo $1 / 10$, durante 25 dias para que as plantas pudessem se estabelecer. Ao final desse perfodo os vasos foram regados com água desmineralizada em abundância, a fim de que fossem "lavados" os nutrientes retidos na silica.

\subsection{Soluçoes Nutritivas}

As soluçóes nutritivas foram preparadas de acordo com SARRUGE (1975), os volumes de cada solugito estoque indicados na Tabela 1 foram colocados em proveta de 1 litro contendo cerca de $100 \mathrm{ml}$ de água desmineralizada, após o que, o volume foi completado até 1 litro também com água desmineralizada.

Tabela 1. Preparaçåo das soluçðes nutritivas para cada tratamento (m//):

\begin{tabular}{|c|c|c|c|c|c|c|c|}
\hline \multirow[b]{2}{*}{ soluçto estoque } & \multirow[b]{2}{*}{ Comp } & \multirow[b]{2}{*}{$-\mathbf{N}$} & \multirow[b]{2}{*}{$-\mathbf{P}$} & \multicolumn{4}{|c|}{ Tratamentos } \\
\hline & & & & $-\mathbf{K}$ & $-\mathrm{Ca}$ & $-\mathbf{M g}$ & -8 \\
\hline $\mathrm{H}_{2} \mathrm{PO}_{4} \mathrm{M}$ & 1 & 1 & - & - & 1 & 1 & 1 \\
\hline $\mathrm{KNO}_{3} \mathrm{M}$ & 5 & - & 5 & - & 5 & 3 & 3 \\
\hline $\mathrm{Ca}\left(\mathrm{NO}_{3}\right)_{2} \mathrm{M}$ & 5 & - & 5 & 5 & - & 4 & 4 \\
\hline $\mathrm{MgSO}_{4} \mathrm{M}$ & 2 & 2 & 2 & 2 & 2 & - & - \\
\hline $\mathbf{K C l} \mathbf{M}$ & - & 5 & $\mathbf{1}$ & - & - & 2 & 2 \\
\hline $\mathrm{CaCl}_{2} \mathrm{M}$ & - & 5 & - & - & - & 1 & 1 \\
\hline $\mathrm{NH}_{4} \mathrm{H}_{2} \mathrm{PO}_{4} \mathrm{M}$ & - & - & - & 1 & - & - & - \\
\hline $\mathrm{NH}_{4} \mathrm{NO}_{3} \mathrm{M}$ & - & - & - & 2 & 5 & - & - \\
\hline$\left(\mathrm{NH}_{4}\right)_{2} \mathrm{SO}_{4} \mathrm{M}$ & - & - & - & - & - & 2 & - \\
\hline $\mathrm{Mg}_{8}\left(\mathrm{NO}_{3}\right)_{2} \mathrm{M}$ & - & - & $=$ & * & - & - & 2 \\
\hline Micromutrientes" & 1 & 1 & 1 & 1 & 1 & 1 & 1 \\
\hline FeEDTA & 1 & 1 & 1 & 1 & 1 & 1 & 1 \\
\hline -Micronutrientes: & $\mathrm{H}_{3} \mathrm{BO}$ & & & & 2,86 & $g / 1$ & \\
\hline & $\mathrm{MnCl}$ & $1 \mathrm{H}_{2} \mathrm{C}$ & & & 1,81 & $g$ & \\
\hline & $\mathrm{ZnCl}$ & & & & 0,10 & & \\
\hline & $\mathrm{CuCl}_{2}$ & & & & 0,04 & $g / 1$ & \\
\hline & $\mathbf{H}_{\mathbf{2}} \mathbf{M o}$ & $\mathrm{n}_{2} \mathrm{U}$ & & & 0,02 & $g /$ & \\
\hline
\end{tabular}


A soluçăo de FeEDTA foi preparada ainda de acordo com SARRUGE (1975). Nos tratamentos com omissăo dos micronutrientes boro e zinco, foram feitas soluços estoque de micronutrientes sem os respectivos elementos.

\subsection{Procedimentos}

Diariamente eram efetuadas duas regas: pela manha, a soluçăo era despejada do recipiente reservatório no vaso, deixando-se a soluçăo escoar pela mangueira até que o nivel da soluçăo ficasse em $1 / 3$ da capacidade do vaso. No final da tarde, a soluçăo era recirculada para que a sllica se mantivesse úmida durante a noite, periodo em que a soluçăo permanecia no vidro reservatório.

As trocas de soluçăo foram feitas com intervalos de 15 dias no começo do experimento, e tornaram-se mais frequentes (ate 7 dias) no final do experimento. Em periodos de calor intenso, os vasos com plantas de maior porte consumiam a solução rapidamente, neste caso, se completava o volume com água destilada até a posterior troca de solução.

\subsection{Corte e destilaça}

Aposs acompanhamento da evoluçăo das deficiências, as plantas foram cortadas a uma altura de $10 \mathrm{~cm}$, a fim de que fossem avaliadas as produçðes de massa verde (MV)e de óleo essencial. Logo em seguida, as plantas foram pesadas e levadas ao equipamento para destilação.

O material colhido de cada vaso, foi cortado em pedaços menores de aproximadamente $5 \mathrm{~cm}$, e colocado num balăo de fundo redondo de capacidade 2 litros. Em seguida adicionou-se $650 \mathrm{ml}$ de água destilada. Acoplado à boca do balăo, foi colocado um cotovelo seguido de um condensador de vidro ligado à outro cotovelo, 
desembocando em um funil de separação. Uma manta aquecedora forneceu o calor necessário para a ebuliçăo da água, que arrastou consigo o óleo essencial. Ao passar pelo condensador a mistura água + óleo se condensou chegando até o funil onde posteriormente, foi efetuada a separação.

O bleo essencial, após ser coletado em um tubo de ensaio devidamente tarado, foi pesado em balança anallitica.

\subsection{Cromatografia a gas}

A avaliaçăo da composiçăo do olleo do $2^{\circ}$ corte, foi feita por cromatografia à gás com detector de ionizaçăo de chama na Seção de Plantas Aromáticas e Fumo do Instituto Agronômico de Campinas, utilizando-se cromatógrafo $\mathrm{CG}^{\circ}$ modelo $37 \mathrm{~S}$, com uma coluna Carbowax 20M com 1/8 de polegada de diâmetro e 2,5 m de comprimento. A temperatura inicial da coluna foi de $70^{\circ} \mathrm{C}$ e a final $180^{\circ} \mathrm{C}$; a programaçăo de aquecimento de $2^{\circ} \mathrm{C}$ por minuto e a temperatura do detector foi mantida a $200^{\circ} \mathrm{C}$. A vazáo do gás foi a seguinte: ar $=200 \mathrm{ml} / \mathrm{min} ; \mathrm{H}_{2}=40 \mathrm{ml} / \mathrm{min}$ e $\mathrm{N}_{2}=2$ $\mathrm{ml} / \mathrm{min}$. A quantidade de amostra injetada foi $1 \mu \mathrm{l}$.

Foram destacados dez picos em cada cromatograma, correspondendo aos principais componentes detectaveis em todas as amostras, $O$ valor da area de cada pico foi tomado em integrador digital Varian ${ }^{\bullet}$ modelo 485 acoplado ao cromatógrafo, sendo a composição percentual do bleo expressa em relação à soma das áreas destes dez picos.

\subsection{Andilise estatistica}

O delineamento experimental foi inteiramente casualizado com 9 tratamentos (completo; -nitrogênio; -fósforo; -potássio; -cálcio; -magnésio; -enxofre; -boro e -zinco) e 4 repetiçðes, totalizando 36 vasos. Um dos vasos do tratamento $-\mathrm{Mg}$ 
apresentou problemas com o pegamento e foi descartado. No segundo corte, por problemas na recuperaçåo do material destilado, nåo foram obtidos os dados de produçăo de bleo de dois vasos, um do tratamento $-\mathrm{N}$ e outro do tratamento -P. Para simplificaçăo da andise estatística as variáveis dessas repetiçסes nåo entraram na análise deste corte (Apêndice 1). As fotografias foram tiradas pouco antes de cada corte.

Os dados de produçáo (MV e bleo), rendimento (percentagem de oleo na MV) percentual dos componentes principais, após analise de variancia, foram submetidos ao teste bilateral de Dumnett utilizando-se o pacote estatistico "SANEST". Os dados de composiçăo sofreram também analises multivariadas do tipo "stepwise discriminant function" e "canonical discriminant function" (MANLY, 1986), efetuadas no programa "S.A.S".

\section{RESULTADOS E DISCUSSAO}

\subsection{Sintomatologia das deficiências}

Alguns dos sintomas de deficiencia, só foram notados após o corte. Provavelmente a absorçăo desses nutrientes na fase de implantaçăo em que se forneceu soluçăo completa, ainda que pequena, foi suficiente para manter um status minimo, de modo a nåo afetar, de maneira visivel, alguns tratamentos. $O$ corte acelerou a manifestaçăo de sintomas e a diferença nas variaveis quantitativas.

\subsubsection{Tratamento completo}

As plantas do tratamento completo apresentaram bom desenvolvimento, perfilhamento normal, folhas bem desenvolvidas com coloração verde intensa, apresentando um ligeiro secamento dos ápices (Figura 2 foto central). $O$ envelhecimento 
de folhas foi considerado normal, com secamento gradual das folhas mais velhas caracteristico de gramineas bem nutridas.

\subsubsection{Omisšxo de nitrogênio}

As plantas com supressão de nitrogênio foram as que primeiro demonstraram sintomas de deficiência. Por volta da segunda semana aposs o inficio dos tratamentos, as folhas das plantas do tratamento $-\mathrm{N}$, ja apresentavam uma cor notadamente mais clara que as dos demais. Com o passar do tempo, este sintoma se acentuou ficando bem nitida a mudança de coloração em relação ao completo. As folhas mais velhas tornaram-se amarelas seguindo-se um secamento prematuro que evoluia em forma de V, da ponta para o centro da lâmina foliar (Figura 2). Estes sintomas têm, aparentemente, ocorrência generalizada nas gramineas, e também foram descritos por HAAG et al (1965) e WERNER \& HAAG (1972), respectivamente nos gêneros Pennisetum e Panicum.

Houve uma reduçăo geral do desenvolvimento prejudicando tanto o número como o desenvolvimento dos perfilhos (Figura 2). Aposs o corte, a rebrota foi lenta, agravando-se com o passar do tempo a disparidade de desenvolvimento em relação ao tratamento completo (Figura 6). As plantas submetidas a omissão de nitrogênio também tiveram visivel reduçăo do comprimento de folhas.

Os restos de talos deixados pelo conte (porçăo das plantas abaixo de 10 cm) apresentaram um padro de secamento alterado, resultando em uma estrutura coriacea de coloraçăo mais avermelhada que nos demais tratamentos. Aparentemente esta estrutura tem maior dificuldade de apodrecimento. Este sintoma, pode ser observado em muitas áreas de cultivo na regiåo de Porto Soberbo, onde a falta de apodrecimento dos restolhos, dificulta as ceifas subsequentes que, por serem manuais (com faca), tendem a 
ser efetuadas a uma altura cada vez maior. O acúmulo de material morto de diversos cortes acaba por prejudicar a penetraçăo de luz na touceira, diminuindo gradativamente o perfilhamento e consequentemente a produçăo de massa verde.

\subsubsection{Omissio de fósforo}

Além de um ligeiro avermelhamento nos bordos de algumas folhas velhas (Figuras 2 e 3), até o primeiro corte, o tratamento com subtraçăo de fósforo, năo havia apresentado diferenças evidentes em relaçăo ao completo. $O$ crescimento foi praticamente normal, podendo ser constatado pela produçăo de MV, estatisticamente equivalente aos melhores tratamentos (Tabela 2)

Após o corte, ocorreu drástica redução do crescimento, houve prejuizo geral para o vigor das plantas, caracterizado por perfilhos mais finos e menos numerosos, além de folhas mais curtas. $O$ avermelhamento das folhas inferiores (mais velhas) apareceu mais rapidamente, se manifestando também de forma mais intensa. A coloraçăo geral das plantas foi alterada, ficando estas, mais amareladas que as do tratamento completo (Figura 6).

\subsubsection{Omissto de potassio}

Os sintomas se iniciaram por volta da quarta semana de tratamento, caracterizando-se por amarelecimento da ponta e dos bordos das follhas, seguido de secamento bastante rápido, tomando grande parte da area foliar e provocando enrolamento dos bordos em direç̃o ao centro. Algumas folhas, apresentaram escurecimento da nervura central; outras, ainda verdes, se dobraram em torno do eixo

longitudinal. As plantas ficaram com aspecto de cabeleira (as folhas enroladas ou dobradas, tinham a aparencia de fios finos e compridos) (Figura 2). O resultado visual 
destes sintomas, assim como descrito por WERNER (1984), pode ser considerado semelhante ao sapecamento por fogo. Houve reduçăo do crescimento em relaça ao tratamento completo, que acentuou-se com o $1^{\circ}$ corte (Figura 6).

\subsubsection{Omisszo de calcio}

Antes do primeiro corte as plantas apresentaram um desenvolvimento tao bom, ou melhor do que o do tratamento completo. A única caracterfstica deste tratamento em relaçåo ao controle foi a ccorrencia de um maior numero de folhas com secamento do ápice. Afora este fato, o aspecto geral era bastante saudavel (Figura 2).

Após o corte houve uma reduçăo acentuada do vigor das plantas (Figura 6). Além de terem folhas mal formadas, alguns vasos apresentaram perfilhos que brotaram com podrida que atingia o meristema basal e as folhas ainda na primeira fase de desenvolvimento, resultando em um sintoma parecido com o chamado "carvão da cana", que é causado por fungo. A citronela adquiriu um aspecto de enfezamento (folhas mais curtas, e inseridas mais proximas umas das outras) (Figura 6). Esta diminuiçăo do comprimento de folhas também ocorreu nas plantas do tratamento com subtraçăo de boro.

\subsubsection{Omissẵo de magnésio}

Este assim como o tratamento $-\mathrm{Ca}$, não provocou sintomas muito evidentes de carencia nutricional. As plantas apresentaram boa produçå e aspecto saudável (Figura 2). Após o corte, as plantas rebrotaram normalmente, resultando em plantas semelhantes ao tratamento completo.

Alguns sinais da falta desse nutriente apareceram tardiamente, podendo ser notado um certo amarelecimento das folhas mais velhas, combinado com 
avermelhamento das nervuras, dando um padräo listrado as folhas (Figura 6). Houve também uma seca mais acentuada das pontas das folhas em relaçăo ao controle. A arquitetura e o desenvolvimento das plantas não foram afetados assim como em outras gramineas (HAAG 1965; WERNER 1971).

\subsubsection{Omisš̃o de enxofre}

Os sintomas visuais de deficiência de enxofre na citronela começaram a aparecer por volta da segunda semana do tratamento. As folhas novas tomaram uma coloraçăo verde claro uniforme (verde citrina), também descrita por HAAG et al (1965) para o capim-elefante. As folhas velhas se tomaram escuras ou arroxeadas (Figuras 2). Este escurecimento iniciou-se na face inferior da folha passando rapidamente d face superior. $O$ contraste entre os dois tipos de folhas era bastante marcante dentro da mesma planta, dando um aspecto inconfundivel as plantas deficientes neste elemento (Figura 3). A cor púpura também foi constatada por HAAG (1965) na cana-de-açúcar deficiente em enxofre.

Após o corte, as plantas deste tratamento, tiveram a rebrota bastante afetada, com visivel redução do número de folhas. $O$ desenvolvimento geral foi bem menor que o tratamento completo, havendo um amarelecimento geral das folhas (Figura 6) como ocorre no capim-coloniă (HAAG \& DECHEN, 1984).

Os sintomas iniciais da carência de enxofre se diferenciam dos sintomas de deficiência de fósforo pelo tom mais arroxeado, e pelo padrăo de coloracăo que toma praticamente toda a folha, enquanto na deficiência de fósforo, o avermelhamento em forma de V, se concentra na ponta e nos bordos. A Figura 4 mostra a comparaçào de folhas velhas deficientes em fosforo (à direita) e enxofre (no centro), com uma follha de mesma idade do tratamento completo (à esquenda). 


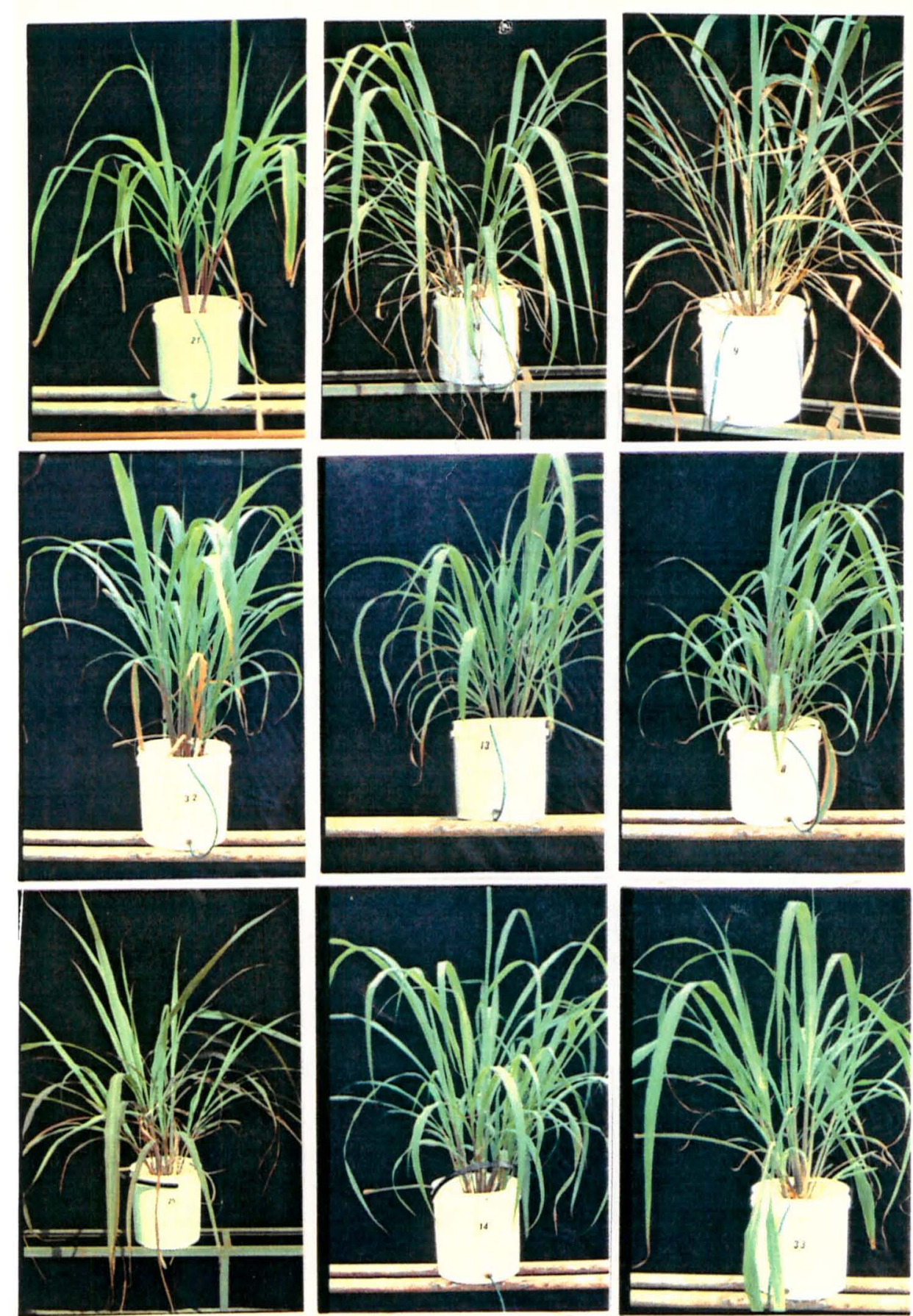

Figura 2. Fotografias dos tratamentos antes do primeiro corte, pela ordem:

- nitrogênio (21)

- cálcio (32)

- enxofre (25)
- fösforo (24)

completo (13)

- boro (14)
- potassio (9)

- magnésio (8)

- zinco (33)

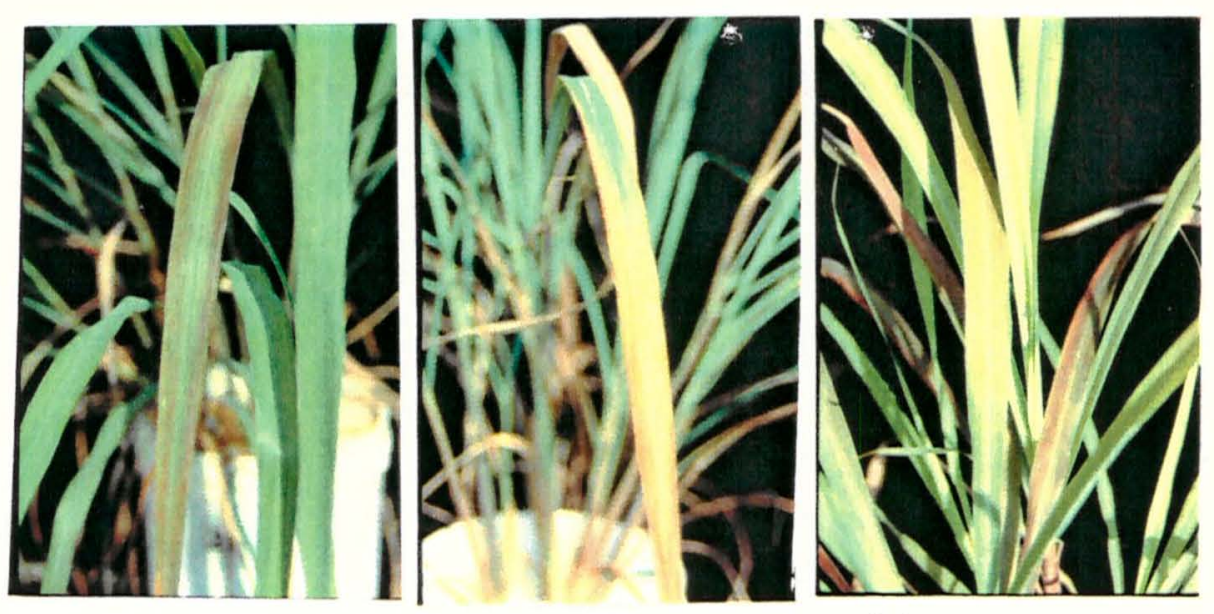

Figura 3. Detalhe de coloraçäo de follhas de plantas deficientes em: fösforo, potássio e enxofre, nesta ordem.

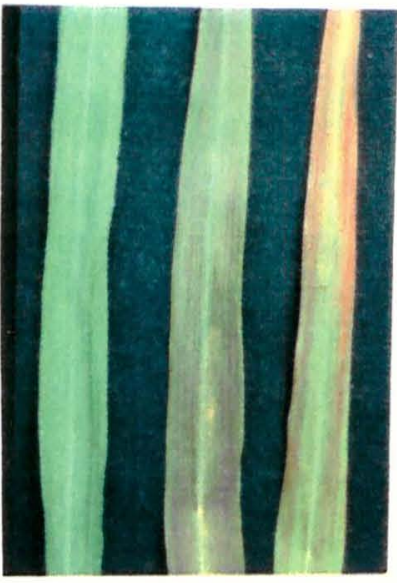

Figura 4. Comparacão entre a coloraça de folhas (velhas) dos tratamentos: completo, -enxofre e -fósforo.

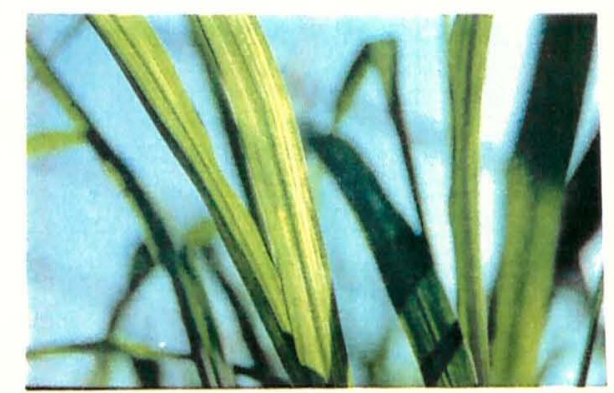

Figura 5. Folha nova de citronela deficiente em boro 


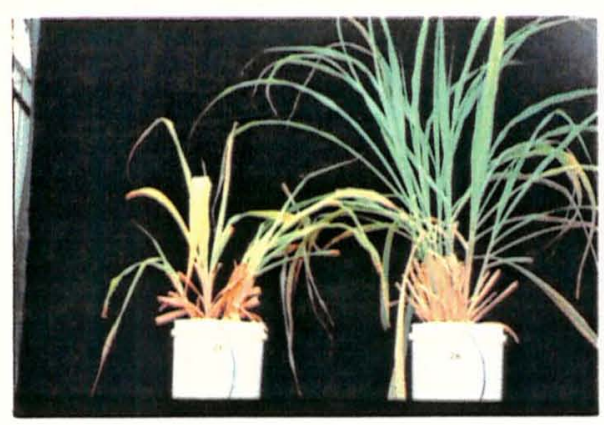

$-N$

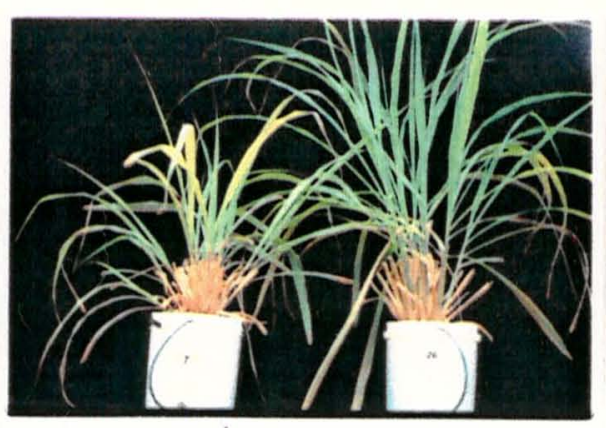

$-P$

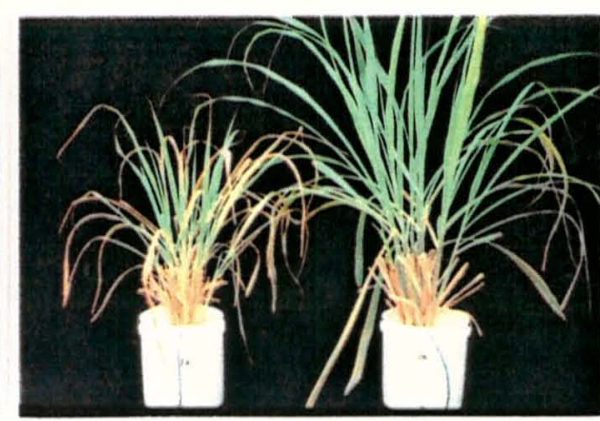

$-\mathrm{K}$

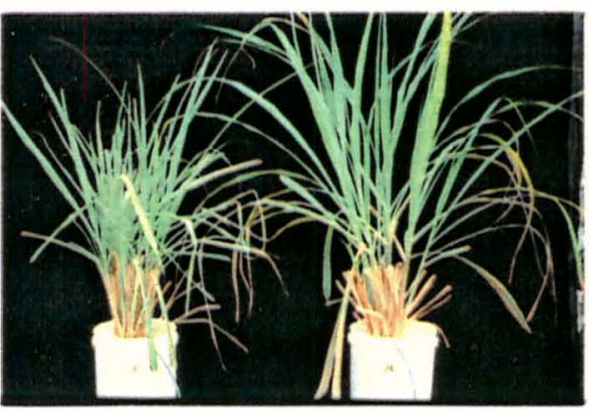

$-B$ completo

completo

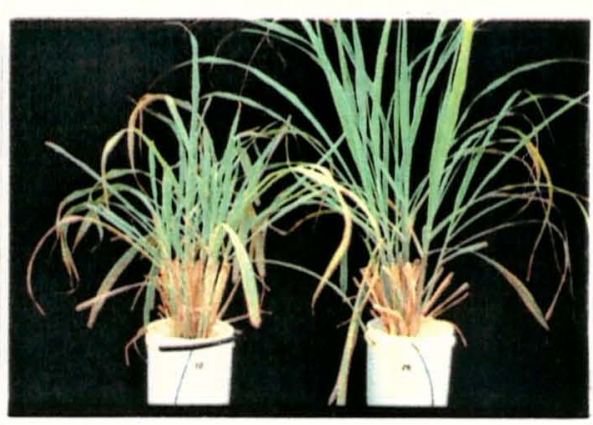

$-\mathrm{Ca}$

completo

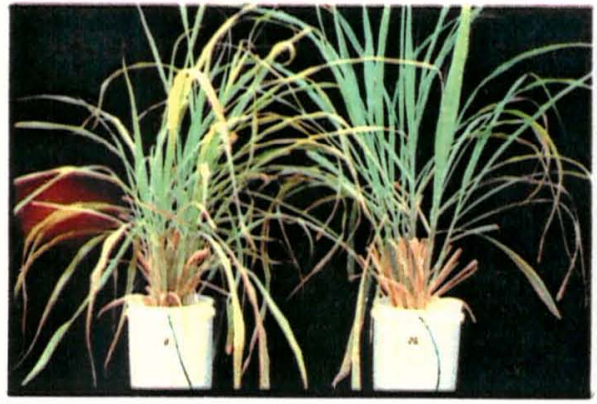

- Mg

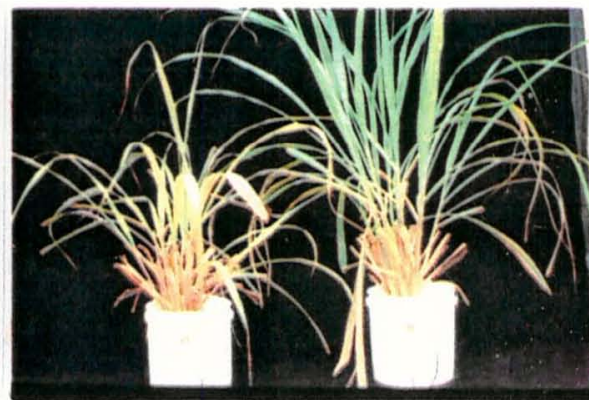

- S completo

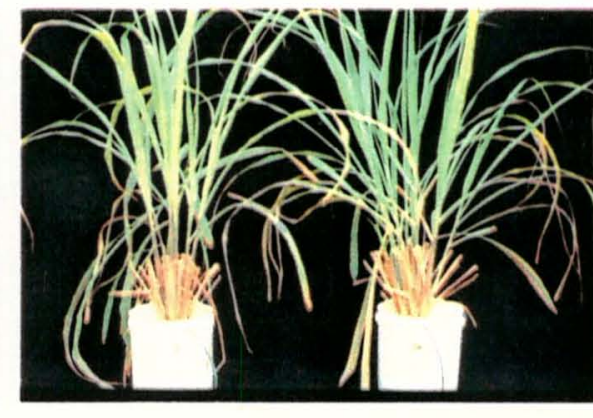

$-\mathrm{Zn}$

completo

Figura 6. Fotografias dos tratamentos com omissão ao lado do completo antes do segundo corte. 


\subsubsection{Omissto de boro}

Este tratamento praticamente nåo apresentou sintomas antes do corte (Figura 2). O comprimento, largura e número de folhas foi semelhante ao tratamento completo. $\mathrm{Na}$ rebrota, as folhas das plantas deficientes em boro mostraram defeitos de formação caracterizados por enrugamento e rachaduras profundas no limbo, localizadas sempre em um dos bordos da lamina. Algumas folhas chegavam a se curvar em direção ao bordo seccionado assumindo a forma de um dedo flexcionado. $O$ limbo apresentou nervuras descontinuas, caracteristica notada principalmente quando a folha era colocada contra a luz (listras transparentes). Em alguns vasos, este sintoma, pôde ser observado mesmo antes do primeiro corte (Figura 5). As folhas brotaram visivelmente mais finas e curtas que as do tratamento completo (Figura 6), produzindo um aspecto ainda mais espigado do que na deficiência de chlcio. A coloraçăo geral năo foi afetada permanecendo o verde escuro semelhante ao completo.

\subsubsection{Omiss $x_{0}$ de zinco}

Năo foram observados sintomas visuais da deficiência de $\mathrm{Zn}$ (Figura 2). Antes do corte algumas folhas apresentaram amarelecimento localizado na base do limbo, o que năo foi considerado suficiente para caracterizar um sintoma de deficiência, já que, teve ocorrência restrita a um dos vasos e não se manifestou após o corte.

\subsection{Produçăo de matéria verde e de óleo}

Os dados de protução de cada vaso no primeiro e segundo corte encontram-se respectivamente no Apêndice 1. Os gráficos a seguir mostram as médias de produção de MV, óleo e a percentagem de oleo na MV para cada tratamento, no primeiro 
e no segundo corte, acompanhados do teste bilateral de Dumett para comparaçáo das médias com o tratamento completo para cada variável.

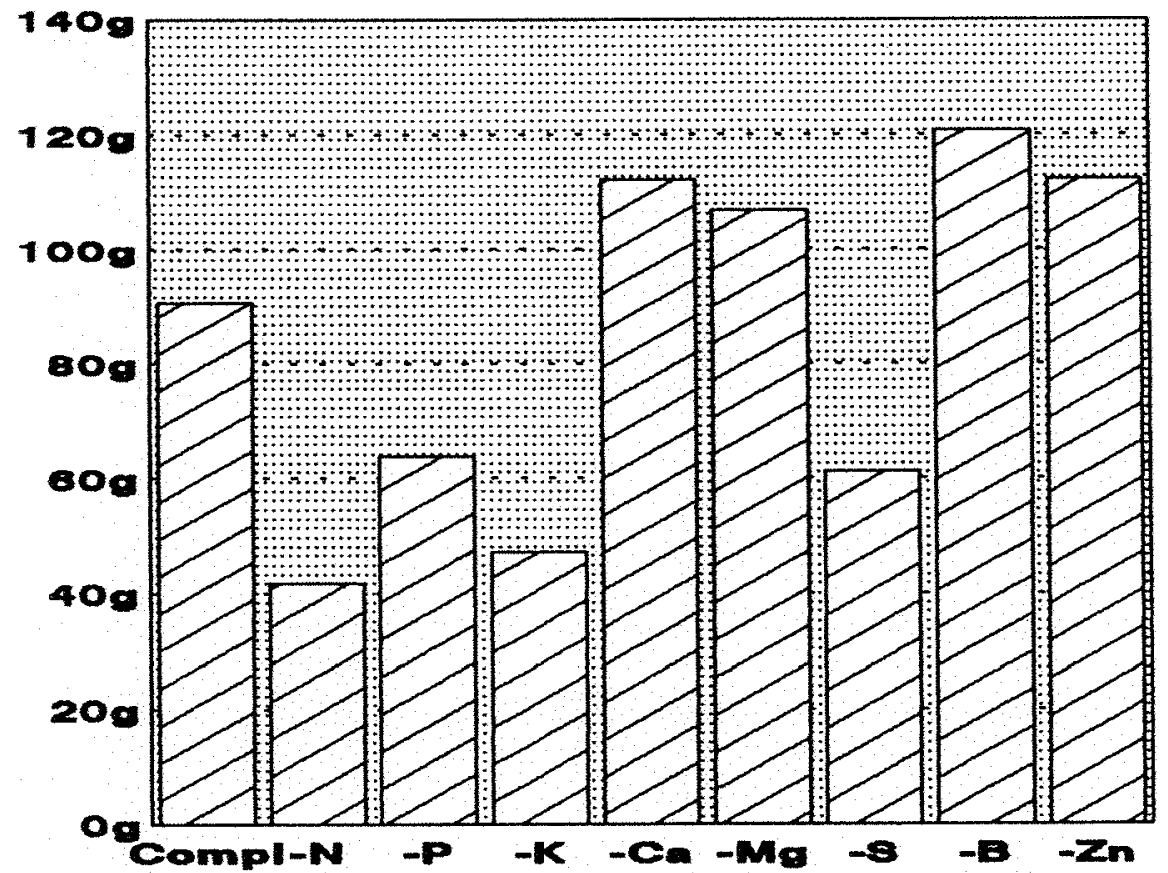

Figura 7. Produçåo de materia verde da citronela no $1^{\circ}$ corte (g/vaso), média das repetiçסes.

Tabela 2. Teste bilateral de Dumnett para as medias dos tratamentos da variável matéria verde (MV) no $1^{\circ}$ corte

\begin{tabular}{lllll} 
NOME & $\mathrm{n}^{\circ}$ de Rep & Media & $5 \%$ & $1 \%$ \\
\hline COMPLETO & 4 & 90.572485 & & \\
$-\mathrm{B}$ & 4 & 120.800003 & NS & NS \\
$-\mathrm{Zn}$ & 4 & 112.362503 & NS & NS \\
$-\mathrm{Ca}$ & 4 & 112.002495 & NS & NS \\
$-\mathrm{Mg}$ & 3 & 106.783335 & NS & NS \\
$-\mathrm{P}$ & 4 & 63.707504 & NS & NS \\
-8 & 4 & 61.055000 & NS & NS \\
$-\mathrm{K}$ & 4 & 46.992500 & $* *$ & $* *$ \\
$-\mathrm{N}$ & 4 & 41.465000 & $* *$ & $* *$ \\
\hline
\end{tabular}

* - TRATAMENTOS QUE DIFEREM DO TRATAMENTO COMPLETO NS - TRATAMENTOS QUE NA̛O DIFEREM DO TRATAMENTO COMPLETO 


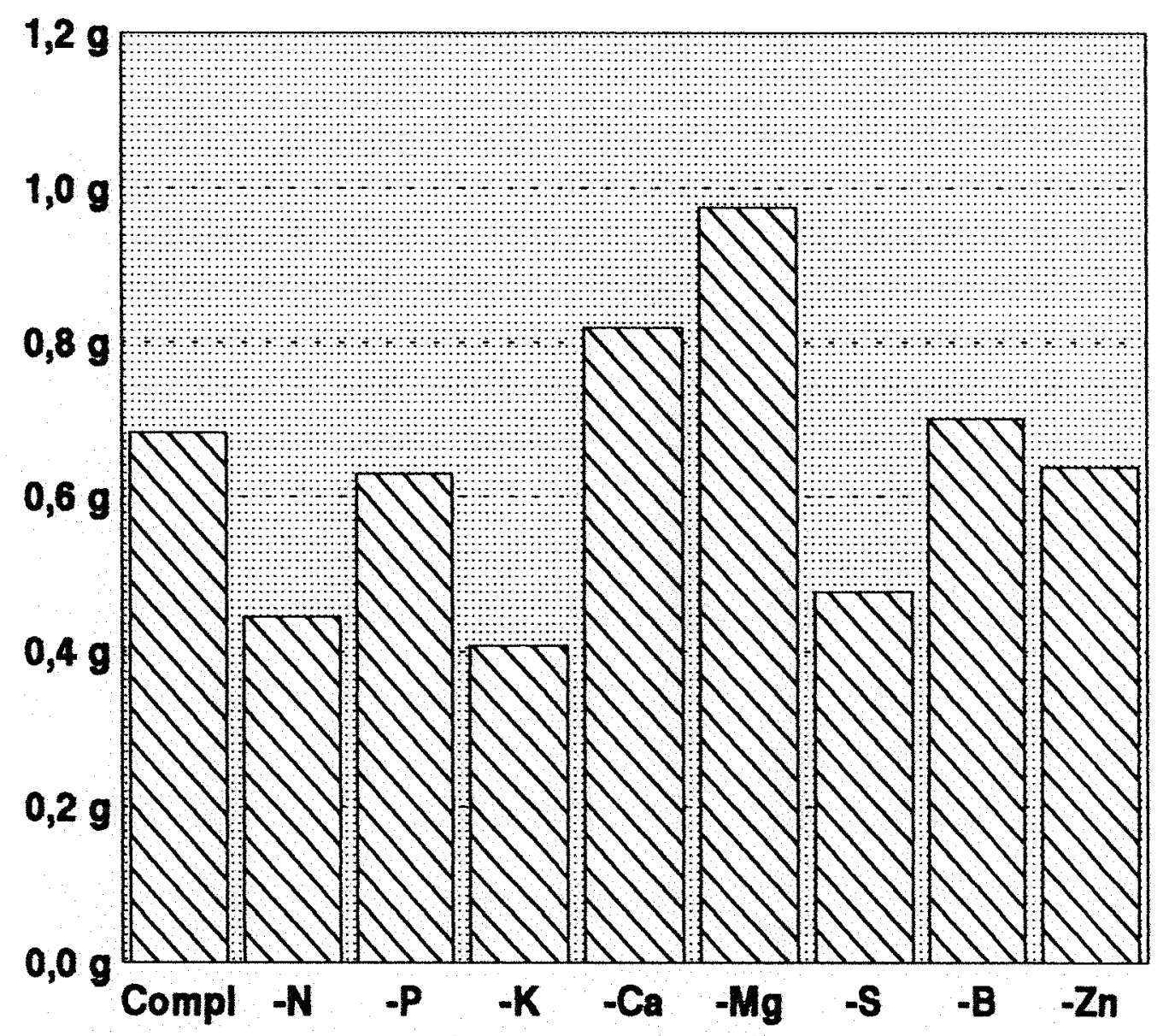

Figura 8. Produçăo de bleo da citronela no $1^{\circ}$ corte (g/vaso), média das repetiçס̄es

Tabela 3. Teste bilateral de Dunnett para as médias de tratamentos da variável produçăo de óleo no $1^{\circ}$ corte

\begin{tabular}{llll} 
NOME & $n^{\circ}$ de Rep & Média & S\% $1 \%$ \\
\hline COMPLETO & 4 & 0.682875 & \\
$-\mathrm{Mg}$ & 3 & 0.974533 & NS NS \\
$-\mathrm{Ca}$ & 4 & 0.818800 & NS NS \\
$-\mathrm{B}$ & 4 & 0.701325 & NS NS \\
$-\mathrm{Zn}$ & 4 & 0.638000 & NS NS \\
$-\mathrm{P}$ & 4 & 0.630025 & NS NS \\
$-\mathrm{S}$ & 4 & 0.477125 & NS NS \\
$-\mathrm{N}$ & 4 & 0.444775 & NS NS \\
$-\mathrm{K}$ & 4 & 0.406525 & NS NS \\
\hline- & 4 &
\end{tabular}

* - TRATAMENTOS QUE DIFEREM DO TRATAMENTO COMPLETO

NS - TRATAMENTOS QUE NAO DIFEREM DO TRATAMENTO COMPLETO 


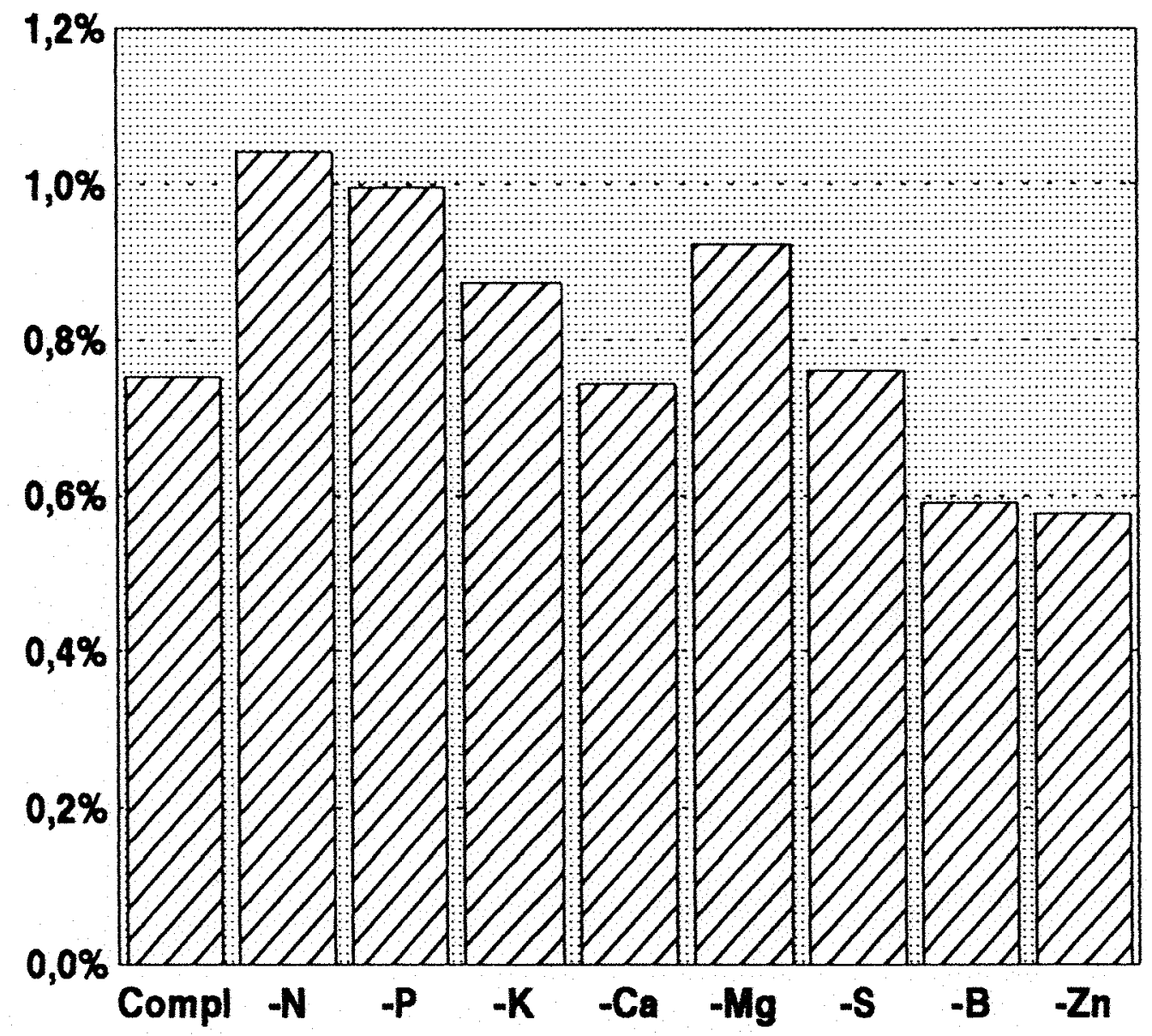

Figura 9. Percentagem de óleo na MV da citronela no $1^{\circ}$ corte (g/vaso)

Tabela 4. Teste bilateral de Dunnett para as médias de tratamentos da variável percentagem de óleo na MV no $1^{\circ}$ corte.

\begin{tabular}{llll} 
NOME & $\mathbf{n}^{\circ}$ de Rep & Média & $5 \% 1 \%$ \\
\hline COMPLETO & 4 & 0.751875 & \\
$-\mathrm{N}$ & 4 & 1.042350 & $*$ NS \\
$-\mathrm{P}$ & 4 & 0.995850 & NS NS \\
$-\mathrm{Mg}$ & 3 & 0.923833 & NS NS \\
$-\mathrm{K}$ & 4 & 0.873500 & NS NS \\
$-\mathrm{S}$ & 4 & 0.760350 & NS NS \\
$-\mathrm{Ca}$ & 4 & 0.743475 & NS NS \\
$-\mathrm{B}$ & 4 & 0.588900 & NS NS \\
- Zn & 4 & 0.576325 & NS NS
\end{tabular}

* - TRATAMENTOS QUE DIFEREM DO TRATAMENTO COMPLETO

NS - TRAT AMENTOS QUE NAO DIFEREM DO TRATAMENTO COMPLETO 


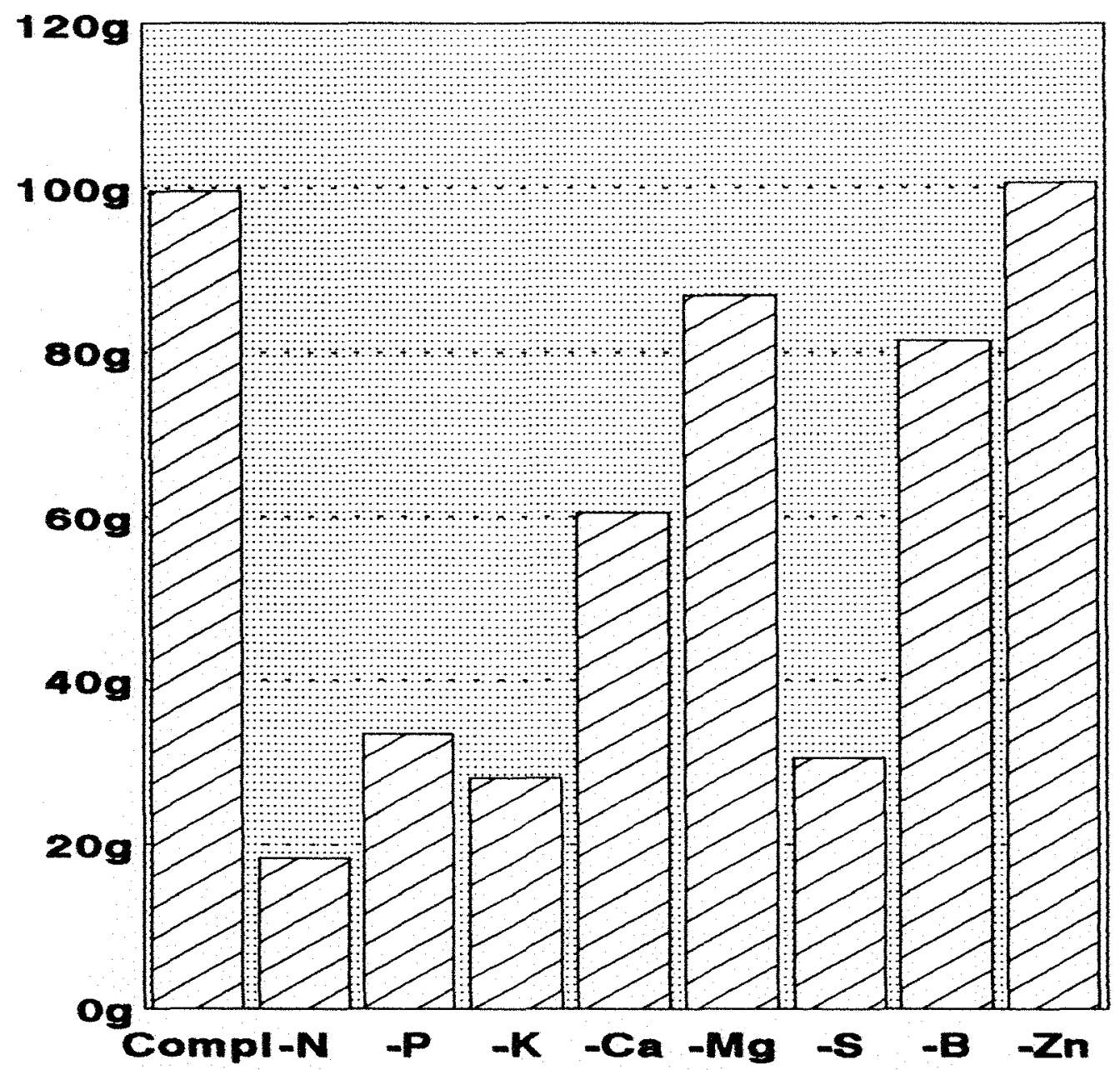

Figura 10.Produção de matéria verde da citronela no $2^{\circ}$ corte (g/vaso)

Tabela 5. Teste Bilateral de Dunnett para as médias de tratamentos da variável produção de matéria verde (MV) no $2^{\circ}$ corte.

\begin{tabular}{|c|c|c|c|c|}
\hline NOME & $n^{\circ}$ de Rep & Médin & $5 \%$ & $1 \%$ \\
\hline COMPLETO & 4 & 99.574997 & & \\
\hline$-\mathrm{Zn}$ & 4 & 100.630005 & & NS \\
\hline$-\mathbf{M g}_{\mathbf{g}}$ & 3 & 87.000000 & NS & NS \\
\hline$-B$ & 4 & 81.447502 & NS & NS \\
\hline$-\mathrm{Ca}$ & 4 & 60.507500 & *** & $* *$ \\
\hline $\mathbf{. P}$ & 3 & 33.183334 & $* *$ & $*$ \\
\hline$-S$ & 4 & 30.422501 & ** & $* *$ \\
\hline$-\mathbf{K}$ & 4 & 27.982502 & $*$ & $* *$ \\
\hline$-\mathrm{N}$ & 3 & 18.303333 & $* *$ & ** \\
\hline
\end{tabular}

* - TRATAMENTOS QUE DIFEREM DO TRATAMENTO COMPLETO NS - TRATAMENTOS QUE NAO DIFEREM DO TRATAMENTO COMPLETO 


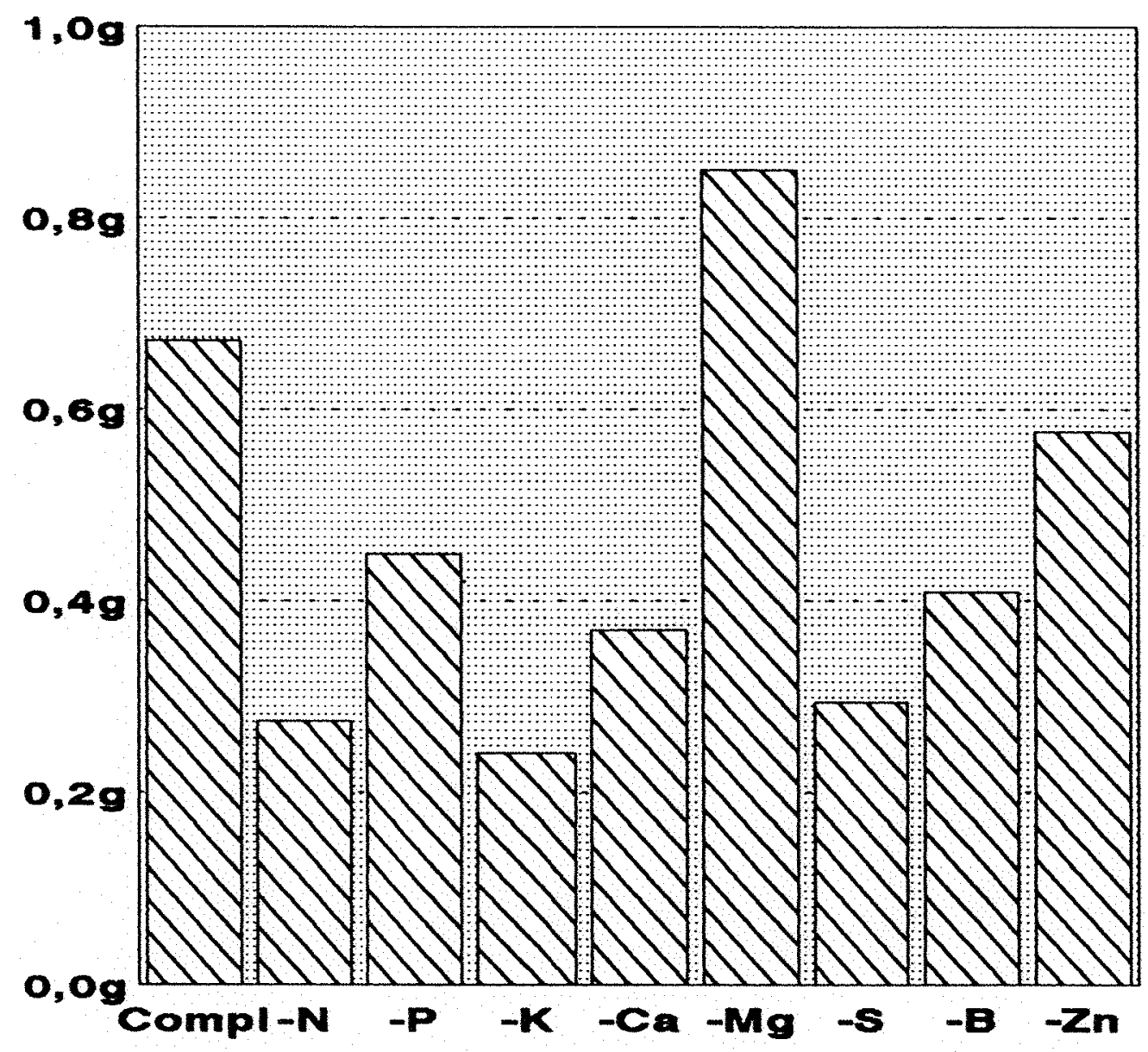

Figura 11.Produção de óleo da citronela no $2^{\circ}$ corte ( $g /$ vaso), média das repetiçðes

Tabela 6. Teste bilateral de Dunnett para as médias de tratamentos da variável produçăo de óleo no $2^{\circ}$ corte

\begin{tabular}{lllll} 
NOME & $\mathrm{n}^{\circ}$ de Rep & Média & $5 \%$ & $1 \%$ \\
\hline COMPLETO & 4 & 0.672100 & & \\
$-\mathrm{Mg}$ & 3 & 0.849567 & NS NS \\
$-\mathrm{Zn}$ & 4 & 0.575650 & NS NS \\
$-\mathrm{P}$ & 3 & 0.448367 & $* *$ & NS \\
$-\mathrm{B}$ & 4 & 0.408125 & $* *$ & $* *$ \\
$-\mathrm{Ca}$ & 4 & 0.369300 & $* *$ & $* *$ \\
$-\mathrm{S}$ & 4 & 0.293425 & $* *$ & $* *$ \\
$-\mathrm{N}$ & 3 & 0.274933 & $* *$ & $* *$ \\
$-\mathrm{K}$ & 4 & 0.240750 & $* *$ & $* *$ \\
\hline
\end{tabular}

* - TRATAMENTOS QUE DIFEREM DO TRATAMENTO COMPLETO NS - TRATAMENTOS QUE NĀO DIFEREM DO TRATAMENTO COMPLETO 


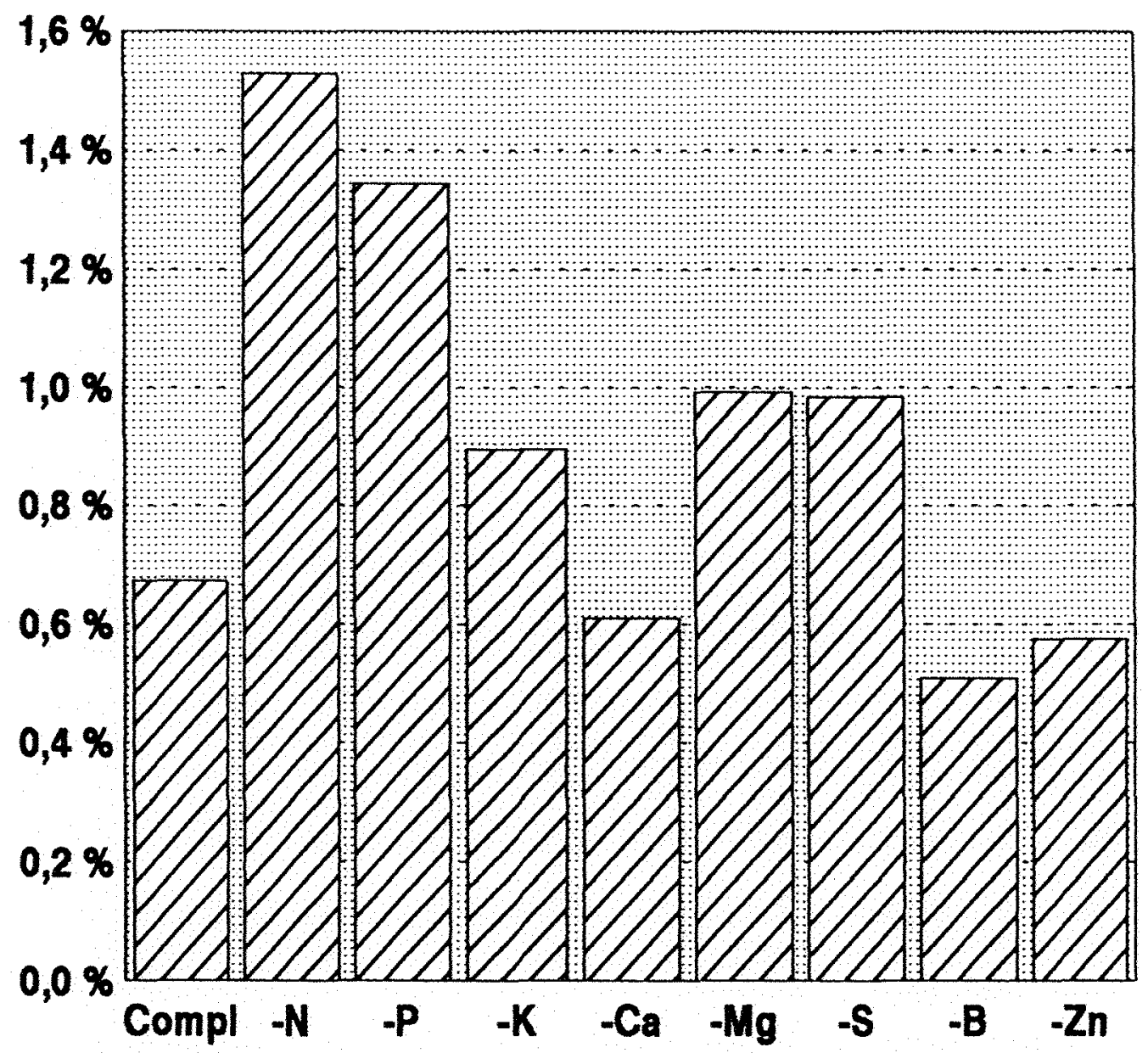

Figura 12.Percentagem de óleo na MV da citronela no $2^{\circ}$ corte ( $\mathrm{g} / \mathrm{vaso}$ ), média das repetiçós

Tabela 7. Teste bilateral de Dunnett para as médias de tratamentos da variável percentagem de óleo na MV no $2^{\circ}$ corte.

\begin{tabular}{|c|c|c|c|c|}
\hline NOME & $n^{\circ}$ de Rep & Média & $5 \%$ & $1 \%$ \\
\hline COMPLETO & 4 & 0.673200 & & \\
\hline$-\mathbf{N}$ & 4 & 1.528200 & ** & ** \\
\hline$-\mathbf{P}$ & 4 & 1.343200 & $* *$ & $* *$ \\
\hline$-\mathbf{M g}$ & 3 . & 0.991767 & ** & NS \\
\hline$-S$ & 4 & 0.982850 & $* *$ & NS \\
\hline$-K$ & 4 & 0.894925 & NS & NS \\
\hline $\mathrm{Ca}$ & 4 & 0.609225 & NS & NS \\
\hline$-B$ & 4 & 0.574850 & NS & NS \\
\hline$-Z \mathbf{n}$ & 4 & 0.507550 & NS & NS \\
\hline
\end{tabular}

** - TRATAMENTOS QUE DIFEREM DO TRATAMENTO COMPLETO NS - TRATAMENTOS QUE NAOO DIFEREM DO TRATAMENTO COMPLETO 
O tratamento completo teve boa produção de folhas, contendo uma percentagem de óleo compativel com os dados apresentados na revisão de GUENTHER (1952), em ambos os cortes.

No primeiro corte so foi possivel detectar diferença significativa $(\mathrm{P}>0,05)$ em relação ao completo, apenas nos tratamentos $-\mathrm{N}$ e $-\mathrm{K}$, e somente para a variável produçăo de MV (Tabela 2). Já no $2^{\circ}$ corte apenas os tratamentos $-\mathrm{Mg}$ e $-\mathrm{Zn}$ não foram diferentes $(P>0,05)$ do completo em alguma das variáveis de produçăo. Estes tratamentos tiveram desenvolvimento, aparentemente superior ao do completo (Figura 10). No caso do -Mg também a produçăo de óleo embora, sem significancia estatistica $(P>0,05)$ foi em media, 0,2g/vaso superior ao tratamento completo (Figura 11; Tabela 6).

Nos tratamentos em que houve supressåo de algum nutriente, nota-se diminuição de produçăo quando se compara o $1^{\circ}$ com o $2^{\circ}$ corte (em média 50\%). Com efeito, enquanto o tratamento completo no $2^{\circ}$ corte, produziu praticamente a mesma quantidade de óleo do $1^{\circ}$ corte (cerca de $98 \%$ ), as plantas do tratamento -Ca, por exemplo, produziram em média, apenas $45 \%$ do que haviam produzido no $1^{\circ}$ (Figura 13 ).

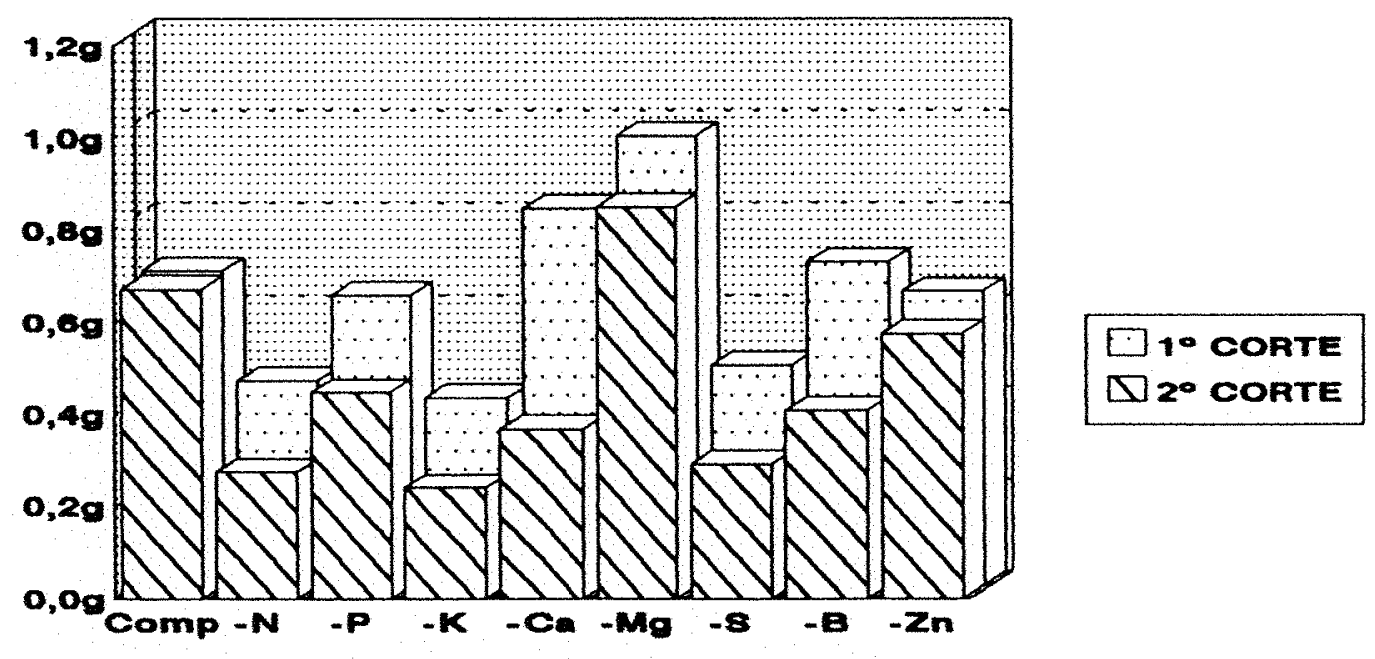

Figura 13. Comparaçăo da média de produção de oleo entre os dois cortes. 
Mesmo nos tratamentos em que nåo houve diferença significativa $(P>0,05)$ em relação ao completo, como no caso do $-\mathrm{Mg}$ ou do $-\mathrm{Zn}$, houve reduçăo na quantidade de oleo produzida (32\% e 10\%, respectivamente), quando comparados os dois cortes.

Além de ter sido o primeiro tratamento a apresentar sintomas de deficiência, a omissăo de nitrogênio resultou na menor produçăo de MV dentre todos os tratamentos, na soma dos dois cortes. Quanto a produçăo de oleo, este também, ao lado do $-\mathrm{K}$ e -S, foi dos mais afetados (Figuras 8 e 11, Tabelas 3 e 6 ).

De conformidade com a conclusåo do trabalho de BOMMEGOWDA et al (1980), a drástica diminuiçăo do número de folhas e perfilhos após o $1^{\circ}$ corte no presente experimento, parece ter sido o principal fator da grande redução da produçăo de oleo no tratamento $-\mathrm{N}$, já que o percentual na $\mathrm{MV}$, foi significativamente maior que no completo $(\mathrm{P}>0,01)$ (Tabela 7). Estes autores explicaram que a adiçăo de $\mathrm{N}$, tem um efeito maior no aumento da área foliar do que sobre o número de glândulas, resultando na diminuiģa na densidade de estruturas secretoras (número de estruturas por centimetro quadrado de folha). Este, segundo eles, é o fator responsável pela redução da percentagem de oleo em citronela adubada com nitrogênio, já que o tamanho e o conteúdo de oleo nas glandulas nåo e afetado.

O experimento de BOMMEGOWDA et al (1980) demonstrou que embora a percentagem de óleo na MV tenha sido maior nas plantas nåo adubadas, a quantidade total de bleo produzida foi significativamente superior nas areas em que se forneceu nitrogênio. Ressalta-se portanto, a necessidade de obtençăo de curvas de produça bo buscando a otimizaçăo do uso de N. Para tanto, os experimentos devem levar em consideração tanto a produça por área como o aumento do custo de destilaçáo causado pela queda da concentração de óleo. 
Assim como ocorreu na subtração do nitrogênio, a falta do fósforo apesar de ter reduzido acentuadamente a produção de MV (Figura 10), teve um efeito menor sobre a produção de óleo (Figura 11), só sendo estatisticamente diferente do tratamento controle no segundo corte e ao nivel de significancia de $5 \%$ (Tabela 6). É interessante notar que enquanto a média de produçåo de bleo neste corte foi cerca de $2 / 3$ da média do óleo produzido pelo tratamento completo, a media de produçåo de MV foi de apenas $1 / 3$ do completo.

Tanto na omissăo de nitrogênio como na de fósforo, a percentagem de oleo na MV aumentou com o avanço da deficiência (comparando-se o primeiro e o segundo corte). Este aumento de rendimento, por começar a ocorrer antes que a proctuçăo seja significativamente afetada (Tabelas 3 e 4), em termos práticos, se acompanhado de sintomas visuais, pode servir de alerta ao produtor quanto a carência desses nutrientes. Algumas áreas de citronela, consideradas de ótimo rendimento na destilaria, podem ter baixa produtividade por área, causadas por carência nutricional.

A supressão de potássio foi o tratamento que mais afetou a produçăo de óleo nos dois cortes. A percentagem na matéria verde nåo foi significativamente alterada $(P>0,05)$, embora também tenha sido numericamente maior que a do tratamento completo. Ja o tratamento - Ca foi o que apresentou maior diferença de produçăo do primeiro para o segundo corte (Figura 13). A produçăo média de oleo, que no primeiro chegou a ser maior que o completo (embora sem diferença estatística) (Figura 8), foi significativamente menor $(\mathrm{P}>0,01)$ no $2^{\circ}$ corte (Tabela 6), acompanhando a rápida evoluçå dos sintomas visuais.

O comportamento mais curioso talvez tenha sido do tratamento em que se omitiu o Mg, pois nos dois cortes, foi este, o que apresentou a maior produçăo de óleo, embora nåo tenha sido em nenhum deles, o de maior produção de MV. No segundo corte, 
foi possivel detectar estatisticamente $(P>0,05)$, um melhor desempenho deste tratamento em relaçăo ao tratamento completo quanto a percentagem de oleo. Embora sem dados conclusivos e, ainda que necessitando de estudos mais especificos, este experimento sugere que deficiencias marginais de $\mathrm{Mg}$ podem vir a se constituir uma interessante prática de manejo para o aumento da produçåo de óleo.

O tratamento $-\mathrm{S}$ foi tåo prejudicial a produçáo quanto os tratamentos $-\mathrm{N}$ e -K, sua caréncia pode ser considerada das mais criticas para a produçăo da citronela. Felizmente os sintomas iniciais de mudança de coloração já descritos, săo bastante nitidos, manifestando-se bem antes que a deficiência comece a afetar significativamente a produção (Tabela 3), deixando bastante tempo para que se corrija o problema.

Os tratamentos $-\mathrm{B}$ e $-\mathrm{Zn}$, foram os que apresentaram as menores médias para a percentagem de óleo na MV nos dois cortes (embora a diferença em relaçăo ao tratamento completo, nåo tenha sido estatísticamente significativa) (Tabela 7). A subtraçăo de $\mathrm{Zn}$, não afetou a produçăo de óleo $(\mathrm{P}>0,05)$ em nenhum dos cortes. $\mathrm{O}$ mesmo nåo ocorreu com a retirada do B que, principalmente no segundo corte, causou perda significativa $(\mathrm{P}>0,01)$ na quantidade de óleo obtida (Tabela 6$)$.

\subsection{Qualidade do Oleo}

A cromatografia revelou dez picos no óleo de citronela, detectados em todas as amostras. Destes os três mais importantes foram identificados atraves de coinjeçăo de padrơes e comparaçăo com cromatogramas conhecidos (MASADA, 1976) e encontram-se assinalados na Figura 14. Os percentuais de cada componente (percentagem em relaçăo a soma dos 10 principais) estăo no Apêndice 2. Os cromatogramas representativos de cada tratamento foram reproduzidos no Apéndice 3. 


\section{Citronelal}

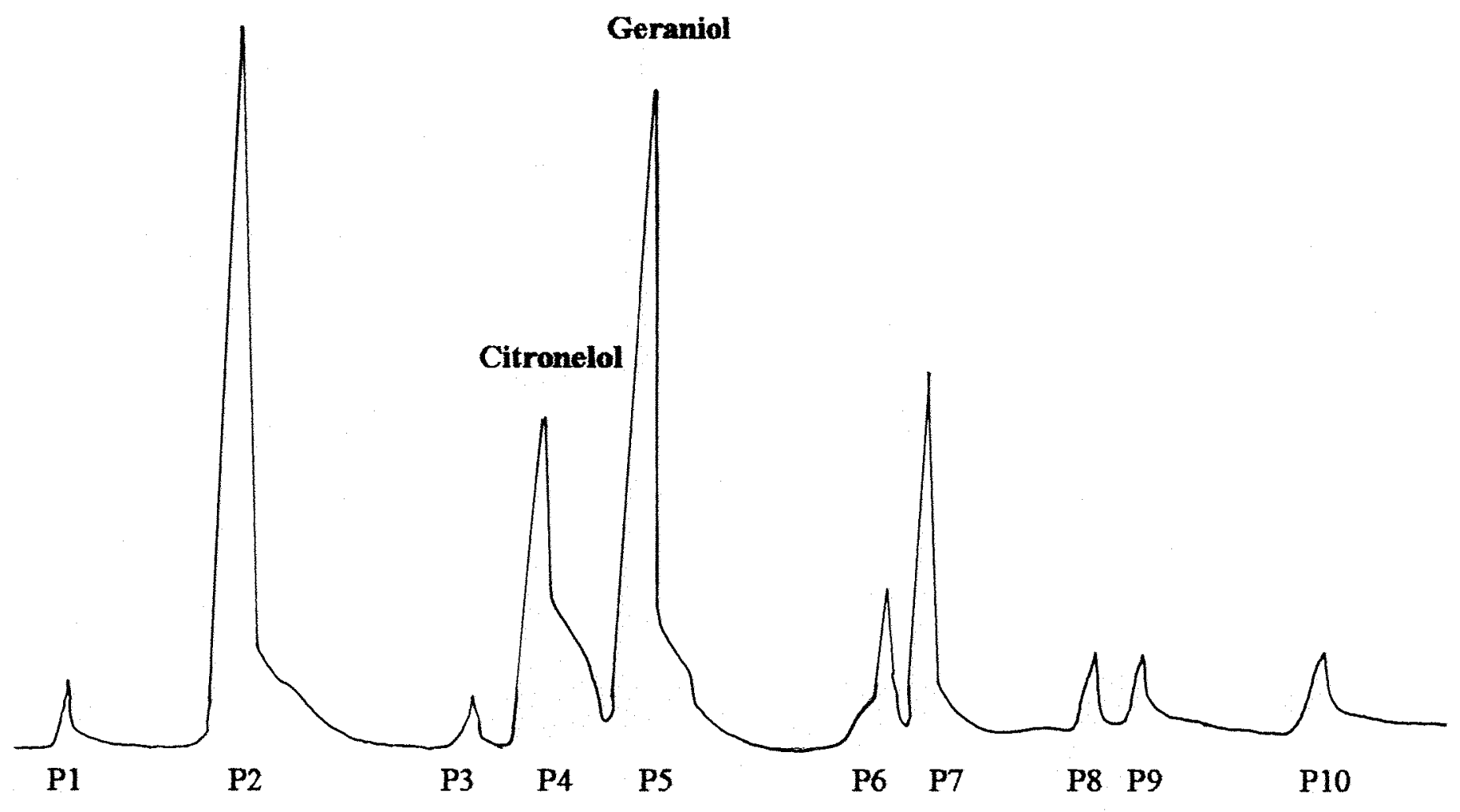

Figura 14. Picos identificados nos cromatogramas de citronela

\subsubsection{Analise univariada dos principais componentes}

\subsubsection{Citronelal}

Apenas o tratamento em que se subtraiu potássio apresentou diferença significativa $(P>0,05)$ na percentagem de citronelal, decaindo em média 9 pontos percentuais (Tabela 8). $\mathrm{O}$ tratamento com supressão de $\mathrm{Mg}$ foi o único que, em relação ao controle, apresentou tendência de elevação desse componente embora năo tenha sido estatisticamente significativa $(\mathrm{P}>0,05)$. 
Tabela 8. Teste bilateral de Dunnett para as médias dos tratamentos da variável citronelal

\begin{tabular}{|c|c|c|c|c|}
\hline NOME & $n^{\circ}$ de Rep & Média & $5 \%$ & $1 \%$ \\
\hline COMPLETO & 4 & 33.324753 & & \\
\hline$-\mathbf{M B}_{\mathbf{B}}$ & 3 & 36.497665 & NS & NS \\
\hline$-\mathbf{p}$ & 3 & 32.331001 & NS & NS \\
\hline$-\mathbf{N}$ & 3 & 31.678668 & NS & NS \\
\hline$-Z \mathbf{n}$ & 4 & 31.382500 & NS & NS \\
\hline$-s$ & 4 & 31.281998 & NS & NS \\
\hline$-\mathrm{Ca}$ & 4 & 30.332752 & NS & NS \\
\hline$-B$ & 4 & 30.208000 & NS & NS \\
\hline$-\mathbf{K}$ & 4 & 24.528000 & $*$ & $* *$ \\
\hline
\end{tabular}

\subsubsection{Citronelol}

Os tratamentos, como mostra a Tabela 9 , nåo influiram significativamente $(\mathrm{P}>0,05)$ na concentraçåo de citronelol em relação à testemunha. Dentre os chamados componentes principais, foi o citronelol, o que apresentou menor variação entre os tratamentos.

Tabela 9. Teste bilateral de Dunnett para as médias dos tratamentos da variavel citronelal

\begin{tabular}{llll}
\hline NOME & $\mathbf{n}^{\circ}$ de Rep & Media & $5 \% 1 \%$ \\
\hline COMPLETO & 4 & 17.033249 & \\
$-\mathrm{Mg}$ & 3 & 18.839333 & NS NS \\
$-\mathrm{Ca}$ & 4 & 18.416000 & NS NS \\
$-\mathrm{K}$ & 4 & 18.195999 & NS NS \\
$-\mathrm{S}$ & 4 & 17.741249 & NS NS \\
$-\mathrm{B}$ & 4 & 17.637501 & NS NS \\
$-\mathrm{N}$ & 3 & 17.445999 & NS NS \\
- Zn & 4 & 16.787500 & NS NS \\
$-\mathrm{p}$ & 3 & 15.949999 & NS NS \\
\hline- & & &
\end{tabular}

** - TRATAMENTOS QUE DIFEREM DO TRATAMENTO COMPLETO NS - TRATAMENTOS QUE NAOO DIFEREM DO TRATAMENTO COMPLETO 


\subsubsection{Geraniol}

A subtraçăo de enxofre demonstrou ser bastante prejudicial a concentraçăo de geraniol que foi reduzida em media $36 \%$, em relaçăo ao controle (Tabela 10). Esta diminuição resultou em grande queda na percentagem total dos componentes principais (Tabela 11). Na análise para fins comerciais este, provavelmente, seria considerado o tratamento mais prejudicial a aceitabilidade do óleo.

Tabela 10. Teste bilateral de Dunnett para as médias dos tratamentos da variável geraniol.

\begin{tabular}{llll}
\hline NOME & $\mathbf{n}^{\circ}$ de Rep & Média & S\% $1 \%$ \\
\hline COMPLETO & 4 & 28.824251 & \\
$-\mathrm{P}$ & 3 & 28.806000 & NS NS \\
$-\mathrm{Zn}$ & 4 & 27.871250 & NS NS \\
$-\mathrm{K}$ & 4 & 27.295250 & NS NS \\
$-\mathrm{B}$ & 4 & 27.138750 & NS NS \\
$-\mathrm{N}$ & 3 & 25.281334 & NS NS \\
$-\mathrm{Mg}$ & 3 & 23.415667 & $*$ NS \\
$-\mathrm{Ca}$ & 4 & 22.737499 & $* *$ NS \\
$-\mathrm{S}$ & 4 & 18.499250 & $* * *$ \\
\hline
\end{tabular}

** - TRATAMENTOS QUE DIFEREM DO TRATAMENTO COMPLETO

NS - TRATAMENTOS QUE NÃO DIFEREM DO TRATAMENTO COMPLETO

\subsubsection{Somatória dos principais componentes}

Esta variável nos dá ideia do valor incustrial do oleo obtido em cada tratamento. Os tratamentos $-\mathrm{S},-\mathrm{K}$ e $-\mathrm{Ca}$ afetaram significativamente $(\mathrm{P}>0,01)$ a soma dos principais componentes. No tratamento - $\mathrm{S}$ o fator responsável foi a queda acentuada do geraniol (Tabela 10), já no -K a diminuição ocorreu no conteúdo de citronelal (Tabela 8), enquanto no - Ca houve queda moderada tanto no citronelal como no geraniol.

$\mathrm{O}$ tratamento - $\mathrm{Mg}$, embora tenha apresentado uma queda significativa $(P>0,05)$ na percentagem de geraniol em relação ao tratamento completo (Tabela 10), 
não demonstrou diminuição significativa $(\mathrm{P}>0,05)$ na soma dos componentes, devido ao aumento relativo da concentraçào de citronelal.

Tabela 11. Teste bilateral de Dunnett para as médias dos tratamentos da variável citronelal + citronelol + geraniol.

\begin{tabular}{llllll}
\hline NOME & n $^{\circ}$ de Rep & Média & & $5 \%$ & $1 \%$ \\
\hline COMPLETO & 4 & 79.752665 & & \\
-Mg & 3 & 78.752665 & NS & NS \\
-p & 3 & 77.087001 & NS & NS \\
-Zn & 4 & 76.041245 & NS & NS \\
-B & 4 & 74.984253 & NS & NS \\
-N & 3 & 74.406001 & NS & NS \\
-Ca & 4 & 71.486252 & $* *$ & $* *$ \\
- K & 4 & 70.019257 & $* *$ & $* *$ \\
- S & 4 & 67.522499 & $* *$ & $* *$ \\
\hline
\end{tabular}

"* - TRATAMENTOS QUE DIFEREM DO TRATAMENTO COMPLETO
NS - TRATAMENTOS QUE NÃO DIFEREM DO TRATAMENTO COMPLETO

\subsubsection{Análise multivariada}

Atraves do S.A.S., foi feita uma análise denominada "stepwise discriminat function analysis" para escolha dos componentes que mais "separam" os tratamentos (MANLY, 1986), cujo resumo encontra-se no ttem g do Apêndice 2.

Os testes de hipótese do efeito dos tratamentos sobre a composição (conjunto dos componentes), e os respectivos valores de $\mathrm{F}$ da análise multivariada săo mostrados no item $\mathrm{f}$ do Apêndice 2.

O gráfico das variaveis canônicas CAN1 X CAN2 (Figura 15) obtido no S.A.S. separa nitidamente os tratamentos $-\mathrm{N}(2),-\mathrm{K}(4),-\mathrm{Mg}(6)$ e $-\mathrm{S}(7)$. Os demais $-\mathrm{P}$ (3); - $\mathrm{Ca}$ (5); - $\mathrm{B}(8)$ e $\mathrm{Zn}$ (9) têm, como demonstrado pela proximidade com o tratamento completo (1), uma composiçăo mais semelhante. 


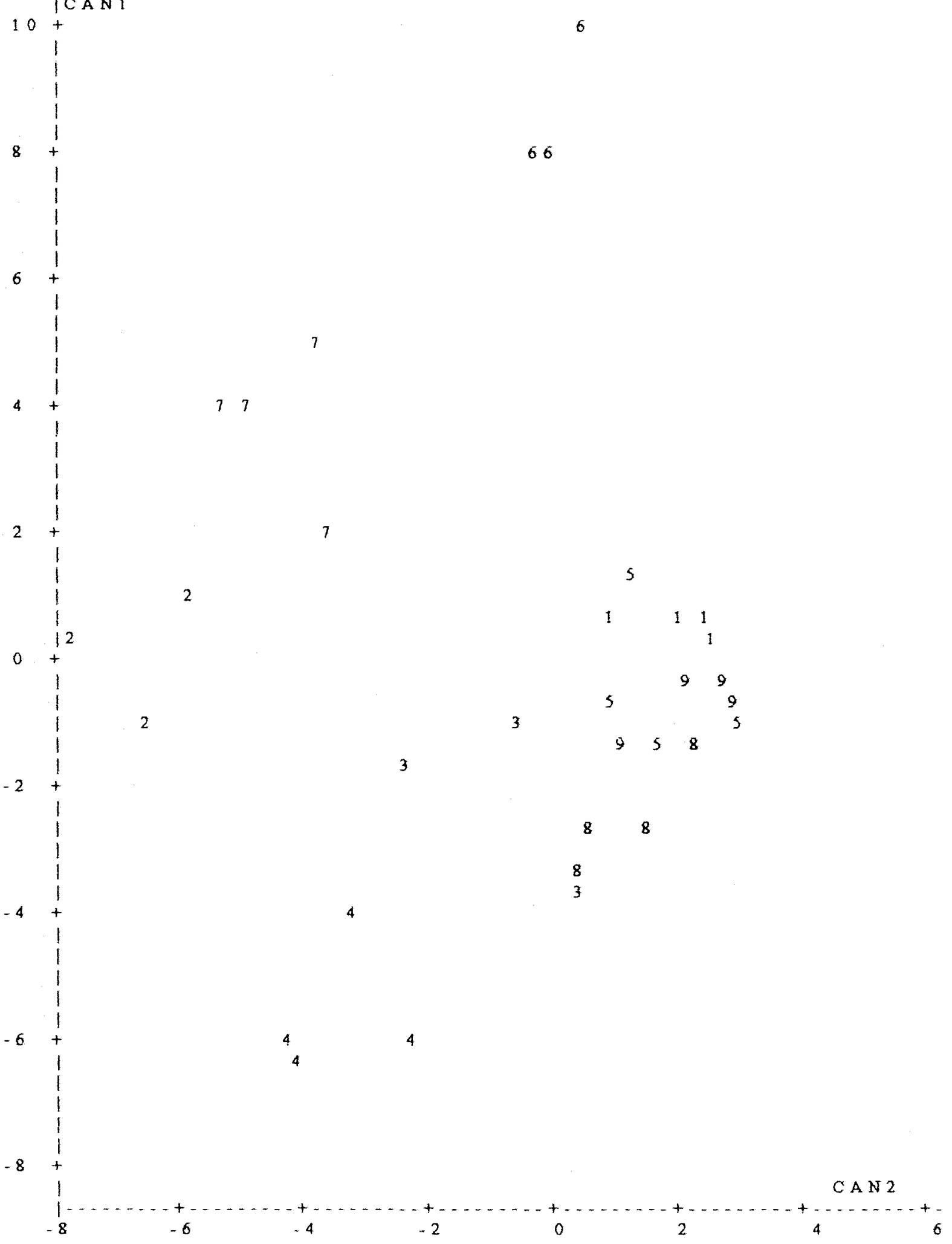

Figura 15 Gráfico das variàveis canónicas obtidas na função discriminante canônica utlilizando a percentagem dos 10 componentes detectados no bleo. 
E importante ressaltar que a função discriminante do tipo "stepwise" (Apêndice 2) mostrou que as variáveis que mais contribuiram para esta disposiçăo espacial dos tratamentos no gráfico das variáveis canônicas, foram por ordem o P8, o P6, o (P1), o geraniol (P5), o P7, o P9, o citronelol (P4) e o citronelal P2, ou seja os picos P8 e P6 foram os que mais efetivamente diferenciaram os tratamentos, o citronelol e o citronelal tiveram pouca participaçăo, enquanto os picos P3 e P10 foram eliminados da análise, por não terem influência discriminante.

A análise multivariada dos componentes do óleo, embora não tenha dado idéia classificatória como a análise univariada (não é possivel saber ao certo qual o melhor bleo, simplesmente pode-se agrupa-los em nichos de proximidade), por levar em consideração uma gama maior de componentes, e em conjunto, pode se tornar uma ferramenta extremamente interessante na avaliaçăo de experimentos que envolvam qualidade do "bouquet" (conjunto dos aromas de cada componente). Para tanto, há necessidade de se fazer uma avaliação sensorial (olfativa) classificatória dos tratamentos, verificando a proximidade ou distancia do padrão comercial, por exemplo, através de uma funçăo discriminante .

Neste trabalho, nå foi sugerida a analise olfativa pois a quantidade de óleo obtida em algumas repetiçðes, năo permitiria uma analise equilibrada para todos os tratamentos, o que indubitavelmente prejudicaria a validade da mesma. Além disso o tipo de destilação utilizado no experimento resulta em padrões olfativos diferentes do padrão comercialmente aceito pelos perfumistas. 


\section{CONCLUSÓES}

Das deficiências estudadas somente a deficiência de zinco năo pôde ser caracterizada. Todas as demais apresentaram sintomas visuais bastante claros. Em algumas deficiências, como as de boro, calcio e magnésio, estes sintomas só se manifestaram apos longo periodo de supressăo do elemento (mais de 60 dias). $O$ corte da planta acelerou a manifestaça dos sintomas.

As carências de potássio, nitrogênio e enxofre foram as que mais afetaram a produçåo de bleo sendo tamberm as que, visualmente, se manifestaram mais cedo.

A percentagem de óleo na matéria verde aumentou com o avanço das deficiências de nitrogênio e fósforo, antes mesmo que a produçăo de óleo fosse significativamente afetada.

Quanto à qualidade do óleo para fracionamento industrial, as deficiências seguramente mais prejudiciais ao rendimento, são as de enxofre e de potássio, que reduziram significativamente as porcentagens de geraniol e citronelal respectivamente.

A análise multivariada demonstrou que os tratamentos $-\mathrm{K},-\mathrm{N},-\mathrm{S}$ e $-\mathrm{Mg}$, foram os que apresentaram o conjunto de componentes mais distante do completo. Esta análise entretanto, carece de uma avaliação sensorial para qualificaçăo dos tratamentos.

Os componetes (picos) que apresentaram maior poder de discriminaçăo dos tratamentos foram o P8 e o P6. Estes dois componentes poderåo, após outros estudos, se tornar parâmetros para a identificaçăo de deficências nutricionais na citronela. Além disso demonstra-se a necessidade da avaliaçăo da influência dos mesmos, e de outros, percentualmente menos expressivos (em relação aos chamados principais: citronelal, citronelol e geraniol) sobre a qualidade olfativa do oleo essencial. 


\begin{abstract}
Alguns dos sintomas observados, principalmente no caso da caréncia de nitrogênio, podem ser encontrados em condiçăo de campo em cultivos comerciais no Brasil, demonstrando que o patamar produtivo da citronela alcançado em outros paises, em nossas condições, não está sendo atingido, em parte por causa de deficiencias nutricionais facilmente detectáveis.
\end{abstract}




\section{REFERENCIAS BIBLIOGRAFICAS}

BOMMEGOWDA, A.; NARAYANA, M. R; KRISHNAMURTHY, K. Response of Java citronella to micronutriens. Indian Journal of Agronomy, New Delhi, 25(3): 568-70. 1980.

BOMMEGOWDA, A.; NARAYANA, M. R.; KRISHNAMURTHY, K; GANESH RAO, R. S. Nitrogen fertilizer use in Java citronella (Cymbopogon winterianus Jowitt). Mysore Joumal of Agricultural Science, Bangalore, 15(1): 60-2, 1981.

BOMMEGOWDA, A; NARAYANA, M. R.; KRISHNAMURTHY, K; GANESH RAO, R. S.; CHANDRASEKHARA, G; PUTTANNA, K. Nutrient content and uptake studies in Java citronella (Cymbopogon winterianus Jowitt). Mysore Journal of Agricultural Science, Bangalore, 17(1): 109-14, 1983.

CHATTERJE, S. K.; NANDI, R. P.; SARKAR, D. P. Effect of mineral nutrients on growth and essential oil formation in Cymbopogon winteriamus. Sience and Culture, Calcutta, 50(1): 26-9, 1984.

DONALISIO, M. G. R. Gramineas Aromáticas (Capim-limåo, Citronela e Palma-rosa). In: RAIJ, B. van; SILVA, N. M da; BATAGLIA, O.C.; QUAGGIO, J. A.; HIROCE, R.; CANTARELLA, H.; BELLINAZZI JR., R.; DECHEN, A. R.; TRANI, P. E. Recomendaçðes de adubação e calagem para o Estado de São Paulo. Campinas, Instituto Agronómico, 1985. 52p. (LAC. Boletim técnico, 100).

FARIA, V. P. de. Técnicas de produçăo de silagens. In: SIMPÓSIO SOBRE MANEJO DA PASTAGEM, 8. Piracicaba, 1986. Anais. Piracicaba, Fealq, 1986. p.119-44.

GUENTHER, E. Essential oils of the plant family gramineae. In: . The Essential Oils. Van Nostrand, Princeton, 1952. v.4. 
HAAG, H. P. Estudos de nutriçæo mineral na cana-de-açúcar (Saccarum afficinarum L.) variedade CB 41-76 cultivada em solução nutritiva. Piracicaba. 1965. 141p. (Livre-docência) - Escola Superior de Agricultura "Luiz de Queiroz"/ USP).

HAAG, H. P. \& DECHEN, A. R. Deficiências minerais em plantas forrageiras. In: SMMṔSIO SOBRE MANEJO DA PASTAGEM, 7., Piracicaba, 1984. Anais. Piracicaba, FEALQ. 1985. p. 139-68.

HAAG, H. P.; MELLO, F. A. F.; BRASIL SOBRINHO, M. O. C.; COBRA NETTO, A.; ANDRADE, R. G.; COELHO, R. G. Estudos sobre a nutriçðo mineral do Pennisetum purpureum Schum, var. napier cultivado em soluçăo nutritiva. In: CONGRESSO INTERNACIONAL DE PASTAGENS, 9, São Paulo 1965. Anais, p. 691-5.

HERATH, H. M. W.; IRUTHAYATHAS, E. E.; ORMROD, D.P. Temperature effects on essential oil composition of citronella selections. Economic Botany, New York, 33(4): 425-30. 1979.

HERATH, H. M. W. \& ORMROD, D. P. Carbon dioxide compensation values in citronella and lemongrass. Plant Physiology, Rockville, 59: 771-2, 1977.

INTERNATIONAL TRADE CENTRE UNCTAD/GATT. Essential oils and oleoresins: a study of selected producers and major markets. Geneva, 1986. 208p.

IRUTHAYATHAS, E. E. \& HERATH, H. M. W. Micro-hairs of citronella leaves and their relationship to components of citronella oil. Tropical Agriculture, Surrey, 59(3): 227-30, 1982.

KIEFER, H. Exploraçăo de plantas aromáticas e oleos essenciais. In: SIMPÓSIO DE ÓLEOS ESSENCIAIS, 1., Campinas, 1986. Anais. Campinas, Fundação Cargill, 1986. p. 15-20.

MALAVOLTA, E. Nutrição mineral. In: FERRI, M. G., coord., Fisiologia Vegetal, Såo Paulo, E.P.U.; EDUSP, 1979. v.1 p. 97-113. 
MALWATKAR, G. M.; KOKJE, B. A.; KELKAR, G. D. Seasonal variations in aldehyde content in oil: leaf yellowing and crinkling and leaf browning in Java citronella (Cymbopogon winteriamus Jowitt). Indian Perfumer, New Delhi, 28(1): 17-23, 1984.

MANLY, B. F. J. Multivariate statistical methods. London, Chapman and Hall, 1986. 159 p.

MASADA, Y. Analysis of essential oils by gas chromatography and mass spectrometry. New York, John Wiley, 1976. 333p

MUNSI, P.S. \& MUKHERJEE, S. K. Response of Java citronella (Cymbopogon winterianus Jowitt) to harvesting intervals with different nitrogen levels. Acta Horticulturae, Wageningen, 188: 225-9, 1986.

PEYRON, L. Sur quelques essences en provenance du Mato Grosso. In: CONGRESSO NTERNACIONAL DE OLEOS ESSENCIAIS, 5., Rio de Janeiro, 1971. Anais da Academia Brasileira de Ciências Suplemento, Rio de Janeiro, 44: 332-40, 1972.

PINTO, A. J. A.; INFORZATO, R.; SANTOS, S. R. dos; ABRAMIDES, E. Efeito da aplicaçåo de hormónios vegetais sobre mudas de citronela. Bragantia, Campinas, 22(67): 807-15, 1963.

PRAKASA, E. V. S. R. \& GANEHSA, R. S. R. Biomass accumulation and nutrient uptake patterns in Java citronella (Cymbopogon winterianus Jowitt). Indian Perfumer, New Delhi, 30(4):487-92, 1986.

PRAKASA, E. V. S. R; SINGH, M.; GANESHA, R. S. R; RAMESH, S. Effect of urea and neem cake coated urea on yield, and concentration and quality of essential oil in Java citronella (Cymbopogon winterianus Jowitt). Journal of Agricultural Science, Cambrige, 104: 477-9. 1985.

PRAKASA, E. V. S. R.; SINGH, M.; NARAYANA, M. R.; CHANDRASEKHARA, G. Relative efficiency of prilled urea and ureasupergranules in Java citronella (Cymbopogon winterianus Jowitt). Fertilizer Research, The Hague, 5: 435-7, 1984. 
ROBBINS, S. R. J. Selected markets for the essential oils of lemongrass, citronella and eucalyptus. Report of The Tropical Products Institute, London. G171: 23-35, 1983.

ROLZ, C; DE LEON, R.; DE ARRIOLA, M. C.; DE CABRERA, S. Biodelignification of lemongrass and citronella bagasse by white-rot fungi. Applied and Enviromental Microbiology, Washington, 52(4): 607-11, 1986.

SALETTE, J. E. Nitrogen use and intensive management of grasses in the wet tropics. In: INTERNATIONAL GRASSLAND CONGRESS, 11., Surfers Paradise, 1970. Proceedings. Sta Lucia, University of Queensland, 1970. p. 404-7.

SARRUGE, J. R.; Soluçðes nutritivas Summa Phytopathologica, Piracicaba, 1(3): 231-3, 1975.

SILVEIRA, A. C. Contribuição para o estudo do capim-elefante (Pennisetum purpureum Schum) como reserva forrageira no tropico. Botucatu, 1976. 2 volumes (Livre-docência - Faculdade de Ciências Médicas e Biológicas / UNESP).

SINGH, K.; CHOWDHURY, A.; SUBRAHMANYAM, K.; CHATTERJEE, B. N.; SINGH, D. V. Influence of amounts and methods of potassium application on yied and quality of citronella Java (Cymbopogon winterianus Jowitt) Journal of Agricultural Science, Cambridge, 115: 247-52, 1990.

SINGH, R. S.; BARUAH, A. K. S.; SINGH, K. K.; GANGULY, D. Effect of copper and boron on the yield and quality of Java citronella (Cymbopogon winteriamus Jowitt) oil. Indian Perfumer, New Delhi, 20(1B): 115-20, 1976.

SINGH, R. S.; PATHAK, M. G.; BODOLOI, D. N. Response of Java citronella cultivars to nitrogen under Jorhat condition. Indian Perfumer, New Delhi, 24(4): 192-8. 1980. 
SINGH, R. S.; PATHAK, M. G.; SINGH, K. K. Dynamics and diurnal changes in oil of Java citronella (Cymbopogon winterianus Jowitt) Indian Perfumer, New Delhi, 23(2): 116-20. 1979.

SINGH, R. S.; SINGH, K.; SINGH, K.; SINGH, J. P. Response of Java citronella (Cymbopogon winterianus Jowitt) to nitrogen, phosphorus and potassium fertilization. Indian Perfumer, New Delhi, 27(3\&4): 153-5. 1983.

SUBBA RAO, A.; SUNDARESHAN, K.; PRABHU, U. H.; SAMPATH, S. R. Chemical composition and nutritive value of spent citronella grass and cottonseed hulls. Indian Journal of Animal Science, New Delhi, 54(11): 1064-5, 1984.

VICENTE-CHANDLER, J.; CARO-COSTAS, R.; EARSON, R. W.; ABRUÑA, F; FIGARELLA, J.; SILVA, S. The intensive management of tropical forages in Puerto Rico. Rio Piedras, University of Puerto Rico Agric. Experiment Station, 1964 (Bull, 187).

WERNER, J. C. Estudos sobre a nutriçăo mineral de alguns capins tropicais. Piracicaba, 1971. 95p. (Doutorado - Escola Superior de Agricultura "Luiz de Queiróz" / USP)

WERNER, J. C. Adubação de pastagens. Nova Odessa, IZ, 1984. 49p. (IZ. Boletim Técnico, 18).

WERNER, J. C. \& MATTOS, H. B. de. Estudo de nutrição do capim gordura (Melinis minutiflora). Boletim da Indústria Animal, Nova Odessa, 29(1): 175-84. 1972.

WIJESEKERA, R. O. B.; JAYAWARDENE, A. L.; FONSEKA, B. D. Varietal differences in the constituents of citronella oil. Phytochemistry, Oxford, 12: 2697-704, 1973. 
Apêndice 1 Produção: dados e análise de variância.

a. Produção de matéria verde, óleo e concentração de óleo na MV no $1^{\circ}$ corte

Trat
Co
Co
Co

-
-
-
-

$-\mathbf{K}$

$-\mathbf{K}$

$-\mathbf{K}$
$-\mathbf{K}$

$-\mathrm{Ca}$

$-\mathrm{Ca}$

$-\mathrm{Ca}$

$-\mathrm{Ca}$

$-\mathbf{M g}_{\mathbf{g}}$

$-\mathrm{Mg}$

$-\mathrm{Mg}$

$-\mathbf{S}$

$-\mathbf{S}$

- $\mathrm{S}$

$-S$

$-\mathrm{B}$

$-\mathrm{B}$

- B

$-B$

$-\mathrm{Zn}$

- Zn

$-\mathbf{Z n}$

$-Z n$

MV

Óleo

$\%$

75,05

92,20

102,36

92,68

0,5761

0,5640

0,7676

0,8704

0,7210

0,6117

0,8503

0,7779

18,86

0,1560

0,8271

56,54

41,48

48,98

0,5842

1,0333

0,5091

1,2273

0,5298

1,0817

45,90

64,72

73,39

0,5051

1,1004

0,5640

0,8714

0,7525

1,0253

0,6985

0,9863

52,62

44,77

0,5380

1,0224

0,3460

0,7728

54,75

0,3861

0,7052

35,83

124,36

86,29

0,3560

0,9936

1,0499

0,8442

0,6910

0,8008

130,46

0,6296

0,4826

0,9047

0,8463

107,77

118,96

0,8697

0,8070

1,0080

0,8473

93,62

1,0459

1,1172

29,00

0,1780

0,6138

67,84

74,84

0,6515

0,9603

0,4759

0,6359

72,54

0,6031

0,8314

0,8381

0,6000

0,6347

132,05

87,72

136,01

0,6724

0,6840

0,6948

0,4916

0,5453

92,32

0,6675

0,7230

0,5219

0,4480

118,71

0,7530

0,6343

121,92

0,6096

0,5000 
b. Produção de matéria verde, bleo e concentraçăo de óleo na MV no $2^{\circ}$ corte

\begin{tabular}{|c|c|c|c|}
\hline Tratamento & $\mathbf{M V}$ & Óleo & $\%$ \\
\hline Completo & 93,27 & 0,6642 & 0,7121 \\
\hline Completo & 96,85 & 0,5025 & 0,5188 \\
\hline Completo & 104,19 & 0,7374 & 0,7077 \\
\hline Completo & 103,99 & 0,7843 & 0,7542 \\
\hline$-\mathbf{N}$ & 03,29 & & \\
\hline$-\mathbf{N}$ & 12,97 & 0,1841 & 1,4194 \\
\hline$-\mathbf{N}$ & 13,97 & 0,2441 & 1,7473 \\
\hline$-\mathbf{N}$ & 27,97 & 0,3966 & 1,4179 \\
\hline$-\mathbf{P}$ & 25,00 & 0,3063 & 1,2252 \\
\hline$-\mathbf{P}$ & 35,32 & 0,5543 & 1,5694 \\
\hline$-\mathbf{P}$ & 34,03 & & \\
\hline$-\mathbf{p}$ & 39,23 & 0,4845 & 1,2350 \\
\hline$\cdot \mathbf{K}$ & 37,13 & 0,2454 & 0,6609 \\
\hline$-\mathbf{K}$ & 27,42 & 0,2133 & 0,7779 \\
\hline$-\mathbf{K}$ & 17,93 & 0,1964 & 1,0954 \\
\hline$-\mathbf{K}$ & 29,45 & 0,3079 & 1,0455 \\
\hline$-\mathrm{Ca}$ & 74,64 & 0,4485 & 0,6009 \\
\hline$-\mathrm{Ca}$ & 35,94 & 0,2191 & 0,6096 \\
\hline$-\mathrm{Ca}$ & 66,77 & 0,5238 & 0,7845 \\
\hline$-\mathrm{Ca}$ & 64,68 & 0,2858 & 0,4419 \\
\hline$-M_{B}$ & 91,45 & 0,8170 & 0,8934 \\
\hline$\cdot \mathbf{M g}$ & 103,34 & 0,9831 & 0,9513 \\
\hline$-\mathbf{M g}$ & 66,21 & 0,7486 & 1,1306 \\
\hline$-S$ & 21,73 & 0,2486 & 1,1440 \\
\hline$-S$ & 31,87 & 0,3172 & 0,9953 \\
\hline$-S$ & 31,47 & 0,2954 & 0,9387 \\
\hline$-s$ & 36,62 & 0,3125 & 0,8534 \\
\hline$-B$ & 83,12 & 0,4316 & 0,5192 \\
\hline$-\mathbf{B}$ & 91,14 & 0,4116 & 0,4516 \\
\hline$-\mathbf{B}$ & 63,36 & 0,3698 & 0,5836 \\
\hline$-B$ & 88,17 & 0,4195 & 0,4758 \\
\hline$-\mathbf{Z n}$ & 93,93 & 0,5942 & 0,6326 \\
\hline$-\mathbf{Z n}$ & 106,88 & 0,5545 & 0,5188 \\
\hline$-\mathbf{Z n}$ & 105,88 & 0,5665 & 0,5350 \\
\hline$-Z n$ & 95,83 & 0,5874 & 0,6130 \\
\hline
\end{tabular}


c. Análise de variancia da variável produçăo de MV no primeiro corte

\begin{tabular}{lrrrrrr} 
Causas da Variaçilo & G.L. & S.Q. & Q.M. & Valor F & Prob. $>$ F \\
\hline Tratamento & 8 & 29953.227 & 3744.153 & 7.1203 & 0.00018 \\
Restduo & 26 & 6810.597 & 261.946 & & \\
\hline & 34 & 36763.824 & & & &
\end{tabular}

Média Geral $=83.319427$

Coeficiente de Variaçato $=19.425 \%$

d. Análise de variância de variavel produçåo de óleo no primeiro corte

\begin{tabular}{|c|c|c|c|c|c|}
\hline Causas da Variaçẫo & G.L. & S.Q. & Q.M. & Valor $F$ & Prob. $>F$ \\
\hline Tratamerto & 8 & 0.96081 & 0.12010 & 5.5363 & 0.00058 \\
\hline Residuo & 26 & 0.56403 & 0.02169 & & \\
\hline Total & 34 & \multicolumn{4}{|c|}{1.5248432} \\
\hline
\end{tabular}

e. Análise de variância da variável percentagem de óleo na MV no primeiro corte

\begin{tabular}{|c|c|c|c|c|c|}
\hline Causas da Variacăo & G.L. & S.Q. & Q.M. & Valor $\mathbf{F}$ & Prob. $>$ F \\
\hline Tratamento & 8 & 0.86238 & 0.10780 & 5.4370 & 0.00064 \\
\hline Residuo & 26 & 0.51550 & 0.01983 & & \\
\hline Total & 34 & \multicolumn{4}{|c|}{1.3778833} \\
\hline
\end{tabular}


f. Análise de variância da variável produção de MV no segundo corte

\begin{tabular}{lrrrrr} 
Causas da Variaça & G.L. & S.Q & Q.M. & Valor F & Prob. $>$ F \\
\hline Tratamento & 8 & 31825.844 & 3978.231 & 33.8133 & 0.00001 \\
Residuo & 24 & 2823.671 & 117.653 & & \\
\hline Total & 32 & 34649.515 & & &
\end{tabular}

Média Geral $=61.143028$

Coeficiente de Variaçăo $=17.740 \%$

g. Análise de variância da variável produção de óleo no segundo corte

\begin{tabular}{l|cccccc} 
Causas da Variacllo & G.L & S.Q. & Q.M. & Valor F & Prob. $>$ F \\
\hline Tratamento & 8 & 1.13731 & 0.14216 & 16.6823 & 0.00001 \\
Residuo & 24 & 0.20452 & 0.00852 & & \\
\hline Total & 32 & 1.3418309 & & &
\end{tabular}

Medin Geral $=0.453212$

Coeficiente de Variação $=20.369 \%$

h. Análise de variância de variável percentagem de oleo na MV no segundo corte

\begin{tabular}{lrrrrrr} 
Causas da Variaça & G.L & S.Q. & Q.M. & Valor F & Prob. $>$ F \\
\hline Tratamento & 8 & 3.36953 & 0.42119 & 21.6449 & 0.00001 \\
Residuo & 24 & 0.46702 & 0.01946 & & \\
\hline Total & 32 & 3.8365509 & & &
\end{tabular}

Média Geral $=0.865452$

Coeficiente de Variaçăo $=16.118 \%$ 
Apêndice 2. Composiçåo do óleo ( $2^{\circ}$ corte): dados e análises.

a. Percentagem relativa dos dez componentes (picos) do óleo de citronela detectados em todos os tratamentos

Componentes

\begin{tabular}{|c|c|c|c|c|c|c|c|c|c|c|}
\hline Trat. & P1 & $\mathbf{P} 2$ & P3 & P4 & P5 & P6 & P7 & P8 & p9 & P10 \\
\hline $\mathrm{mp}$ & 1,617 & 30,770 & 1,587 & 17,587 & 28,780 & 4,027 & 10,204 & 2,923 & 1,440 & 1,065 \\
\hline comp & 0,968 & 33,365 & 1,277 & 16,573 & 28,312 & 4,352 & 8,87 & 2,581 & 1,602 & 2,101 \\
\hline comp & 1,658 & 35,262 & 0,977 & 16,34 & 28,702 & 3,831 & 8,115 & 2,42 & 1,841 & 0,855 \\
\hline comp & 1,633 & 33,902 & 1,063 & 17,633 & 29,503 & 3,755 & 7,224 & 2,415 & 1,853 & 1,018 \\
\hline$-\mathbf{N}$ & 433 & 32,521 & 0,711 & 18,454 & 21,599 & 3,016 & 14,465 & 5,517 & 1,451 & 1,833 \\
\hline$-\mathbf{N}$ & 450 & 29,141 & 1,068 & 17,261 & 24,733 & 345 & 13,115 & 6,963 & 2,693 & 2,231 \\
\hline$-\mathbf{N}$ & 0,521 & 33,374 & 1,136 & 16,623 & 29,512 & 1,143 & 645 & 030 & 2,248 & 1,767 \\
\hline$-p$ & 760 & 33,334 & 1,129 & 14,927 & 28,426 & 2,838 & 11,967 & 3,482 & 1,224 & 1,913 \\
\hline$-\mathbf{P}$ & 0,885 & 31,870 & 1,378 & 16,887 & 29,617 & 3,573 & 6,676 & 3,619 & 3,546 & 1,950 \\
\hline$-\mathbf{p}$ & 0,733 & 31,789 & 1,803 & 16,036 & 28,375 & 4,419 & 11,257 & 2,899 & 1,801 & 0,889 \\
\hline$-\mathbf{K}$ & 523 & 25,009 & 0,617 & 16,161 & 26,47 & 5,575 & 15,374 & 6,116 & 2,354 & 1,801 \\
\hline$-\mathbf{K}$ & 0,462 & 20,970 & 2,082 & 20,353 & 27,292 & 3,861 & 14,601 & 6,500 & 3,136 & 0,744 \\
\hline$-\mathbf{K}$ & 0,488 & 24,739 & 1,02 & 17,687 & 26,165 & 3,746 & 17,477 & 5,853 & 1,575 & 1,250 \\
\hline$-K$ & 0,607 & 27,394 & 1,785 & 18,583 & 29,254 & 2,523 & 12,527 & 4,215 & 1,840 & 1,273 \\
\hline - $\mathrm{Ca}$ & 687 & & 1,940 & 16,863 & 22,838 & 6,709 & & 3,693 & 2,431 & 1,365 \\
\hline$-\mathrm{Ca}$ & 0,302 & 32,716 & 0,459 & 17,166 & 23,647 & 6,631 & 12,677 & 1,499 & 1,366 & 3,837 \\
\hline$-\mathrm{Ca}$ & 1,209 & 26,792 & 2,457 & 20,453 & 28,712 & 4,492 & 10,339 & 3,178 & 1,960 & 0,408 \\
\hline - Ca & 0,683 & 29,312 & 1,292 & 19,182 & 15,753 & 7,091 & 18,625 & 4,529 & 2,464 & 1,06 \\
\hline$-\mathbf{M g}$ & & & 2,418 & 8,008 & 24,074 & 53 & 31 & & 06 & 1,855 \\
\hline$-\mathbf{M B}_{\mathbf{B}}$ & 1,707 & 40,120 & 2,368 & 18,521 & 22,357 & 3,054 & 6,408 & 2,551 & 2,197 & 0,716 \\
\hline$-\mathbf{M g}$ & 1,370 & 32,789 & 3,200 & 19,989 & 23,816 & 4,166 & 7,499 & 3,844 & 2,585 & 0,741 \\
\hline$-\mathbf{S}$ & 0,108 & & 2,168 & 17,677 & 17,816 & 4,840 & & 5,697 & 87 & 2,526 \\
\hline$-S$ & 0,807 & 32,5 & 1,770 & 18,536 & 17,747 & 4,704 & 10,683 & 6,545 & 5,110 & 1,585 \\
\hline$-S$ & 0,646 & 29,883 & 1,758 & 17,390 & 20,139 & 5,088 & 12,187 & 6,559 & 4,565 & 1,785 \\
\hline$-S$ & 0,671 & 31,646 & 1,787 & 17,362 & 18,295 & 4,718 & 9,846 & 7,85 & 6,307 & 1,519 \\
\hline$-\mathrm{B}$ & 10 & & 1,057 & 16,294 & & 5,626 & 10 & 94 & 70 & 1,758 \\
\hline$-\mathrm{B}$ & 0,512 & 31,681 & 1,513 & 18,278 & 27,297 & 5,544 & 9,177 & 2,533 & 2,050 & 1,414 \\
\hline$-\mathbf{B}$ & 0,656 & 30,576 & 0,651 & 16,901 & 27,673 & 5,088 & 11,036 & 3,387 & 1,962 & 2,069 \\
\hline$-\mathrm{B}$ & 0,887 & 26,576 & 2,677 & 19,077 & 26,085 & 6,554 & 10,165 & 4,134 & 3,286 & 0,55 \\
\hline$-\mathbf{Z n}$ & 1,399 & 29,992 & 1,701 & 17,2 & 29,747 & 4,415 & & 2,915 & 1,771 & 1,338 \\
\hline$-\mathbf{Z n}$ & 1,071 & 31,424 & 1,368 & 16,183 & 26,214 & 6,592 & 8,919 & 3,771 & 3,035 & 1,423 \\
\hline$-\mathbf{Z n}$ & 1,061 & 32,735 & 0,739 & 17,626 & 25,739 & 5,471 & 6,922 & 4,222 & 4,337 & 1,148 \\
\hline$-\mathrm{Zn}$ & 1,660 & 31,379 & 1,133 & 16,140 & 29,785 & 4,191 & 11,139 & 2,493 & 0,837 & 1,24 \\
\hline
\end{tabular}


b. Análise de variância da variável citronelal.

\begin{tabular}{lrrrrrr} 
Causas da Variaçăo & G.L. & S.Q. & Q.M & Valor F & Prob>F \\
\hline Tratamento & 8 & 291.49825 & 36.43728 & 7.2694 & 0.00016 \\
Residuo & 24 & 120.29776 & 5.01241 & & \\
\hline Total & 32 & 411.79602 & & & \\
\hline & & & &
\end{tabular}

Médis Geral $=31.083454$

Coeficiente de Variaça $=7.203 \%$

c. Análise de variância da variável citronelol.

\begin{tabular}{lrrrrr} 
Causas da Variação & G.L & S.Q. & Q.M. & Valor F & Prob.>F \\
\hline Tratamento & 8 & 20.91966 & 2.61496 & 1.9348 & 0.10083 \\
Residuo & 24 & 32.43735 & 1.35156 & & \\
\hline Total & 32 & 53.35701 & & & \\
\hline
\end{tabular}

Média Geral $=17.574303$

Coeficiente de Variação $=6.615 \%$

d. Análise de variância da variável geraniol.

\begin{tabular}{lrrrrr} 
Causas da Variação & G.L. & S.Q. & Q.M & Valor F & Prob. $>$ F \\
\hline Tratamento & 8 & 362.8544 & 45.3568 & 7.4508 & 0.00014 \\
Residuo & 24 & 146.0996 & 6.0875 & & \\
\hline Total & 32 & 508.9540 & & & \\
\hline
\end{tabular}

Média Geral $=25.514364$

Coeficiente de Variaçăo $=9.670 \%$

e. Analise de variância da variável citronelal + citronelol + geraniol.

\begin{tabular}{lrrrrr} 
Causas da Variaçăo & G.L & S.Q. & Q.M. & Valor F & Prob. $>$ F \\
\hline Tratamento & 8 & 480.3290 & 60.0411 & 7.1203 & 0.00018 \\
Residuo & 24 & 202.3776 & 8.4324 & & \\
\hline Total & 32 & 682.7066 & & \\
& & & \\
Média Geral $=$ & 74.172119 \\
Coeficiente de Variaçalo $=$ & $3.915 \%$
\end{tabular}


f. Análise da multivariância da percentagem relativa dos 10 componentes (picos) de cada tratamento segundo quatro testes.

\begin{tabular}{|c|c|c|c|c|c|}
\hline & Valor & F & Num DF & Den DF & Pr $>$ F \\
\hline 'ilks' Lambda & 0.00003264 & 5.3113 & 380 & 103.7047 & 0.00001 \\
\hline 1 & 4.47485780 & 2.7927 & 80 & 176 & 0.00001 \\
\hline vley Trace & 49.43095061 & 8.1870 & 80 & 106 & 0.00001 \\
\hline thest Root & 22.80590805 & 50.1730 & 10 & 22 & 0.00001 \\
\hline
\end{tabular}

g. Resumo da seleçăo das variáveis (componentes) que mais diferenciam os tratamentos efetuada pela função discriminante "stepwise".

33 Observations 10 Variable(s) in the Analysis

9 Class Levels 0 Variable(s) will be included

Stepwise Selection: Summary

Variable Number Partial F Prob >

\begin{tabular}{llllll} 
Step & Entered Removed & In & $R^{2}$ & Statistic & $F$ \\
\hline 1 & C8 & 1 & 0.7989 & 11.918 & 0.0001 \\
2 & C6 & 2 & 0.7516 & 8.699 & 0.0001 \\
3 & C1 & 3 & 0.7410 & 7.866 & 0.0001 \\
4 & C5 & 4 & 0.7334 & 7.222 & 0.0001 \\
5 & C7 & 5 & 0.5560 & 3.131 & 0.0183 \\
6 & C9 & 6 & 0.6689 & 4.798 & 0.0024 \\
7 & C4 & 7 & 0.5271 & 2.508 & 0.0502 \\
8 & C2 & 8 & 0.6263 & 3.561 & 0.0132
\end{tabular}

Average

Squared

Variable Number Wilks' Prob $<$ Canonical Prob $>$ Step Entered Removed In Lambda Lambda Correlation ASCC

$\begin{array}{llllllll}1 & \text { C8 } & 1 & 0.20110176 & 0.0001 & 0.09986228 & 0.0001 \\ 2 & \text { C6 } & 2 & 0.04995394 & 0.0001 & 0.18387026 & 0.0001 \\ 3 & \text { C1 } & 3 & 0.01294046 & 0.0001 & 0.24857730 & 0.0001 \\ 4 & \text { C5 } & 4 & 0.00344968 & 0.0001 & 0.33511299 & 0.0001 \\ 5 & \text { C7 } & & 5 & 0.00153165 & 0.0001 & 0.37835763 & 0.0001 \\ 6 & \text { C9 } & 6 & 0.00050713 & 0.0001 & 0.43273807 & 0.0001 \\ 7 & \text { C4 } & 7 & 0.00023983 & 0.0001 & 0.48072510 & 0.0001 \\ 8 & \text { C2 } & 8 & 0.00008963 & 0.0001 & 0.50945620 & 0.0001\end{array}$


61
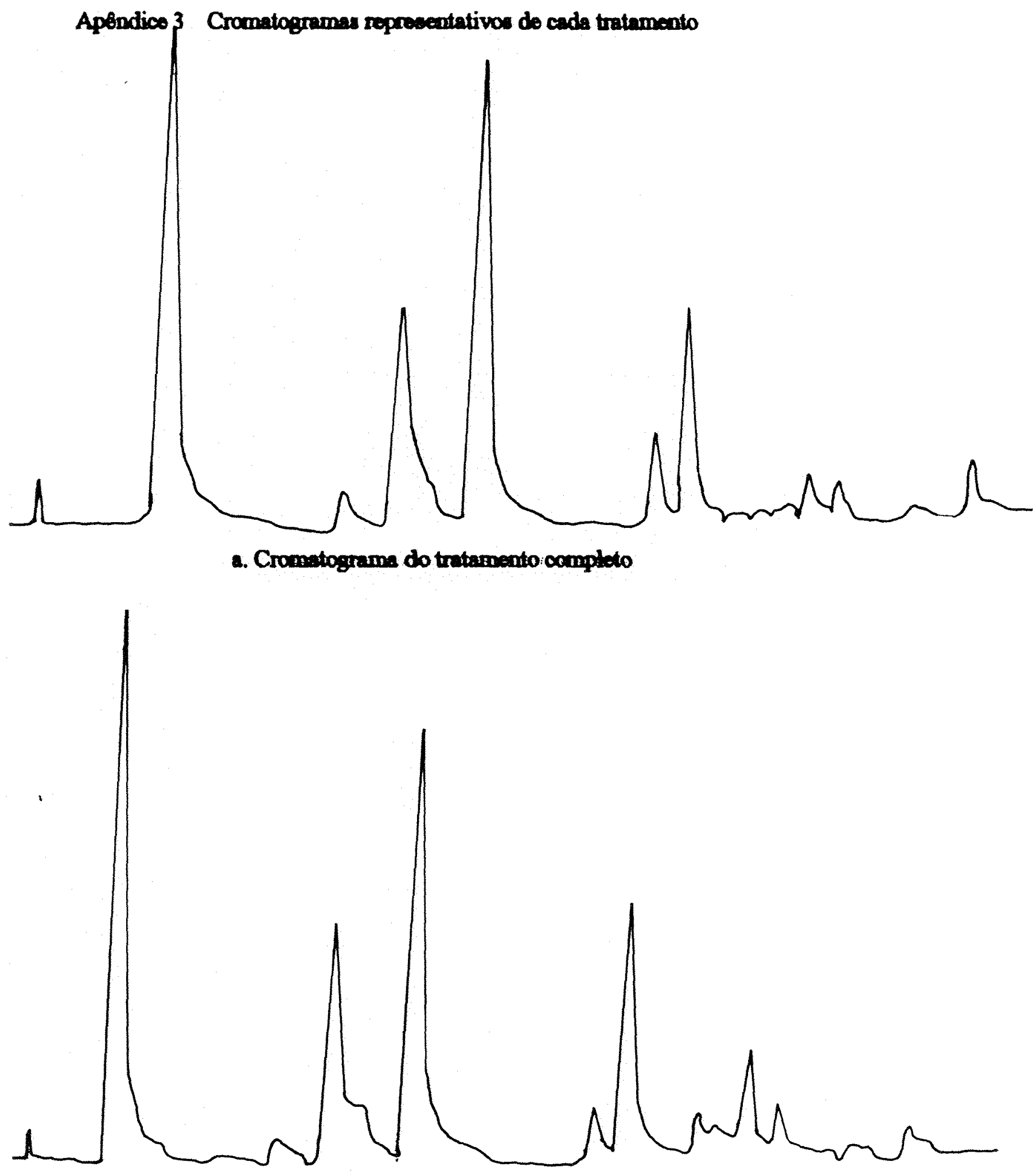

b. Cromatograma do tratamento com cmissto de nitrogenio 
62

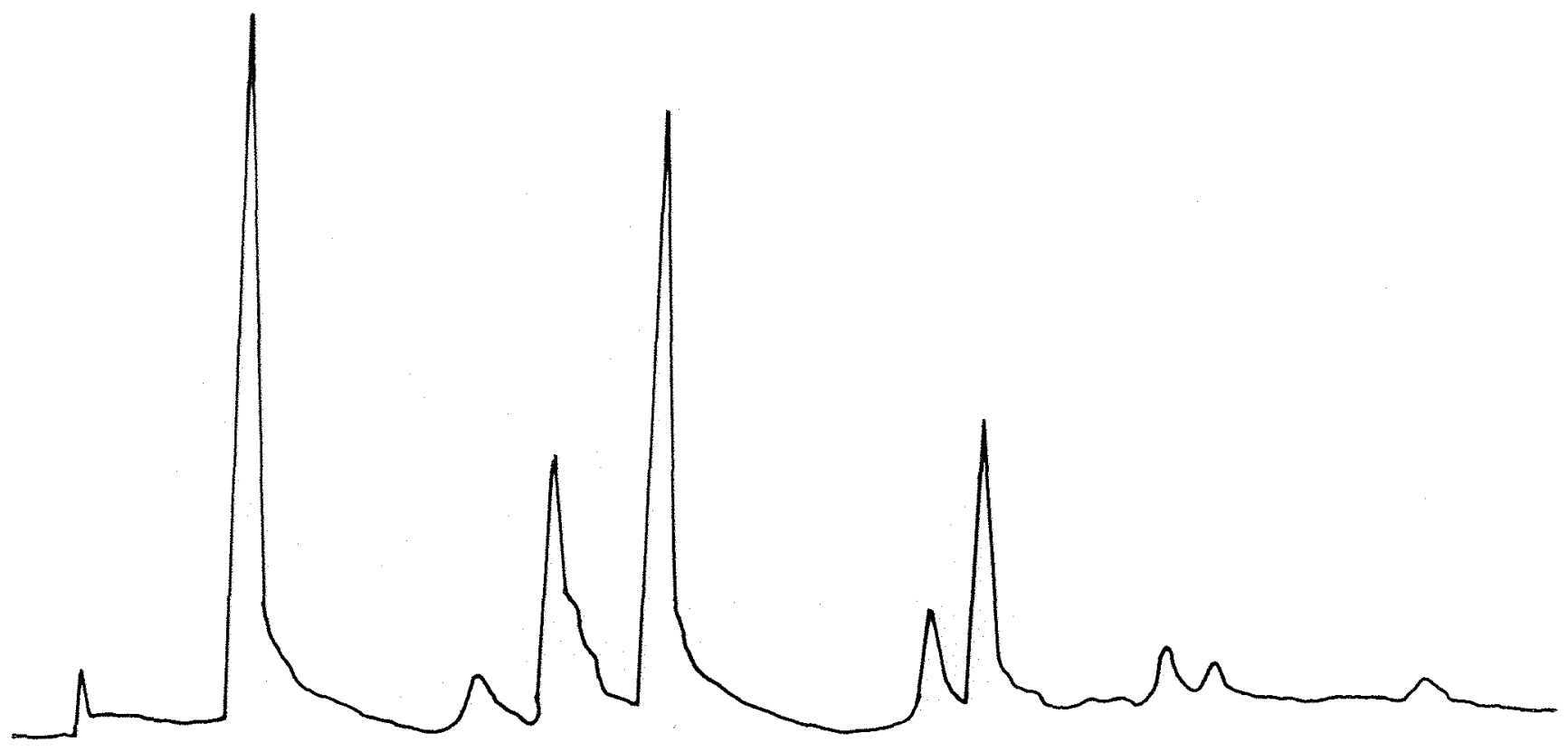

c. Cromatograms do tratamento com amissto de fosforo

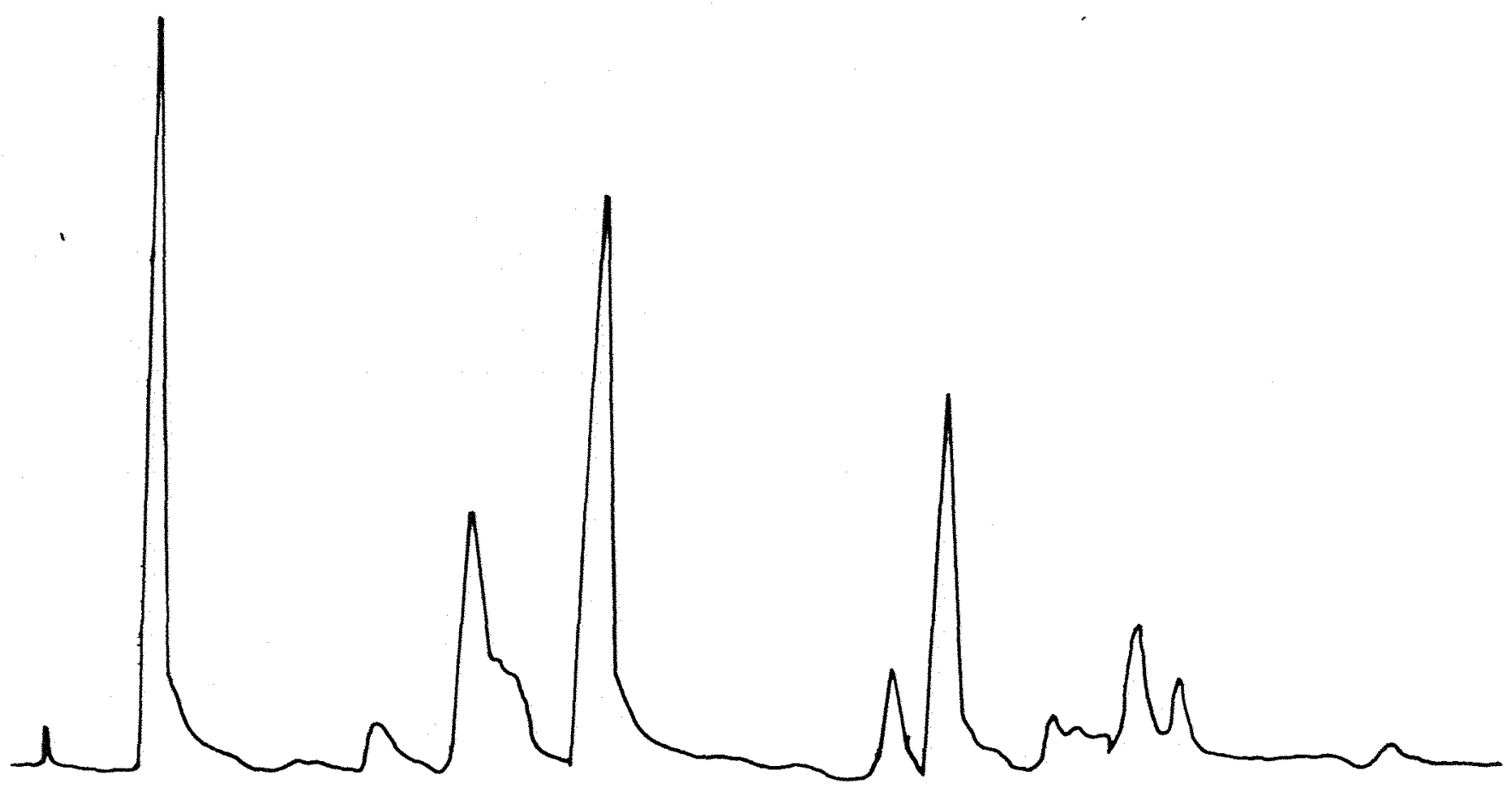

d. Cromatograma do tratamento com omisullo de pothssio 
63

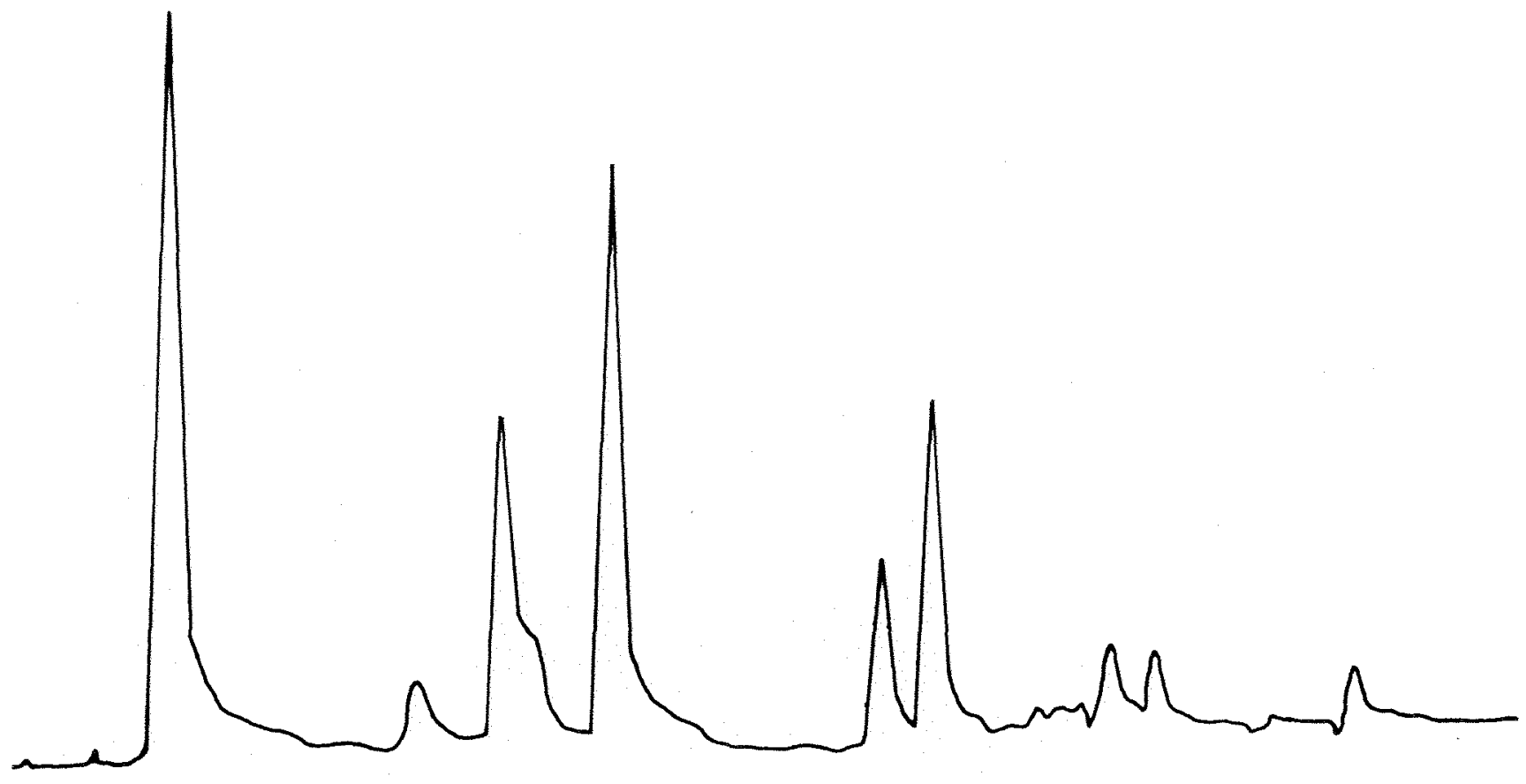

e. Cromatograma do tratamento com omisslo de calcio

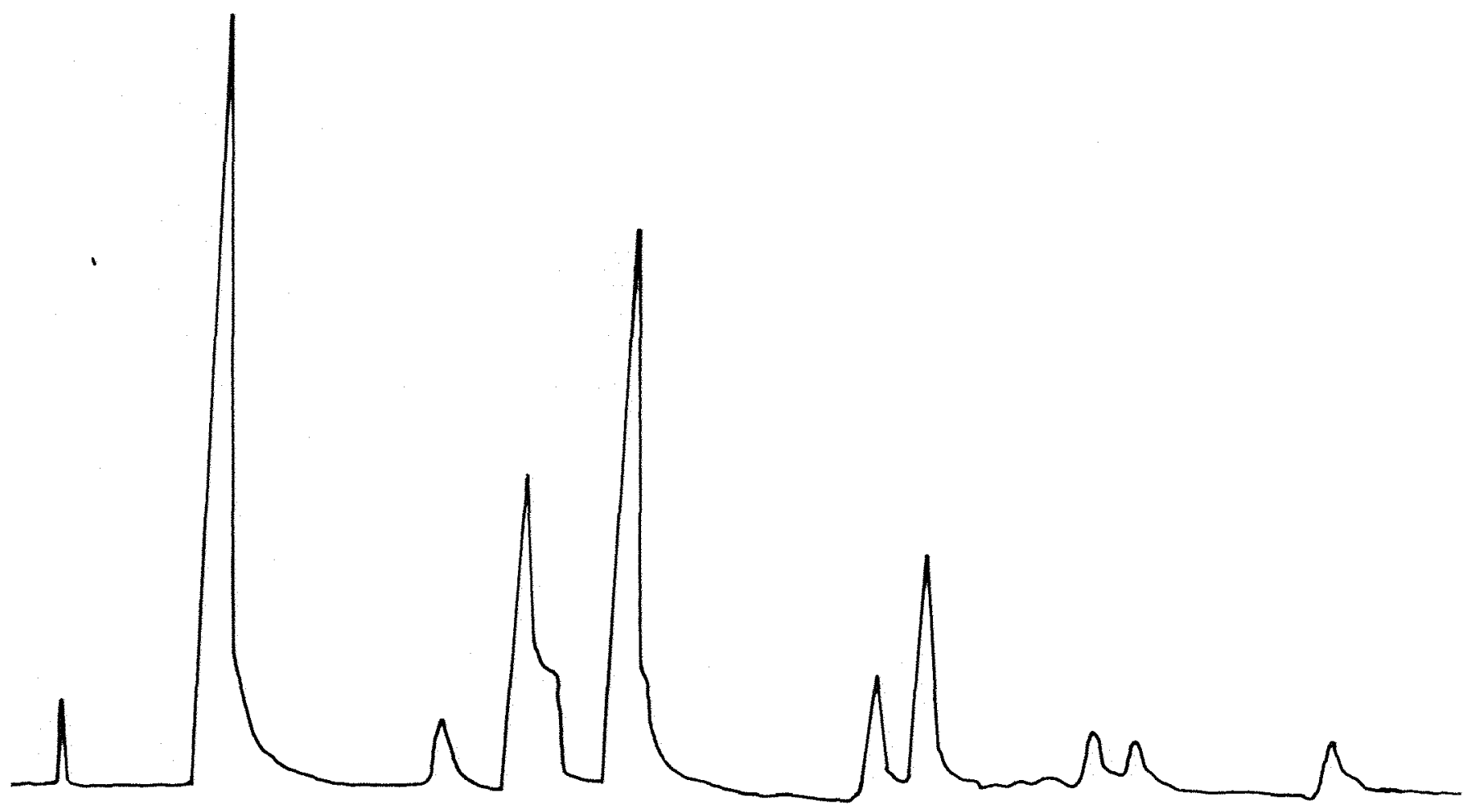

f. Cromatograms do tratamento com conisslo de magnosio 
64

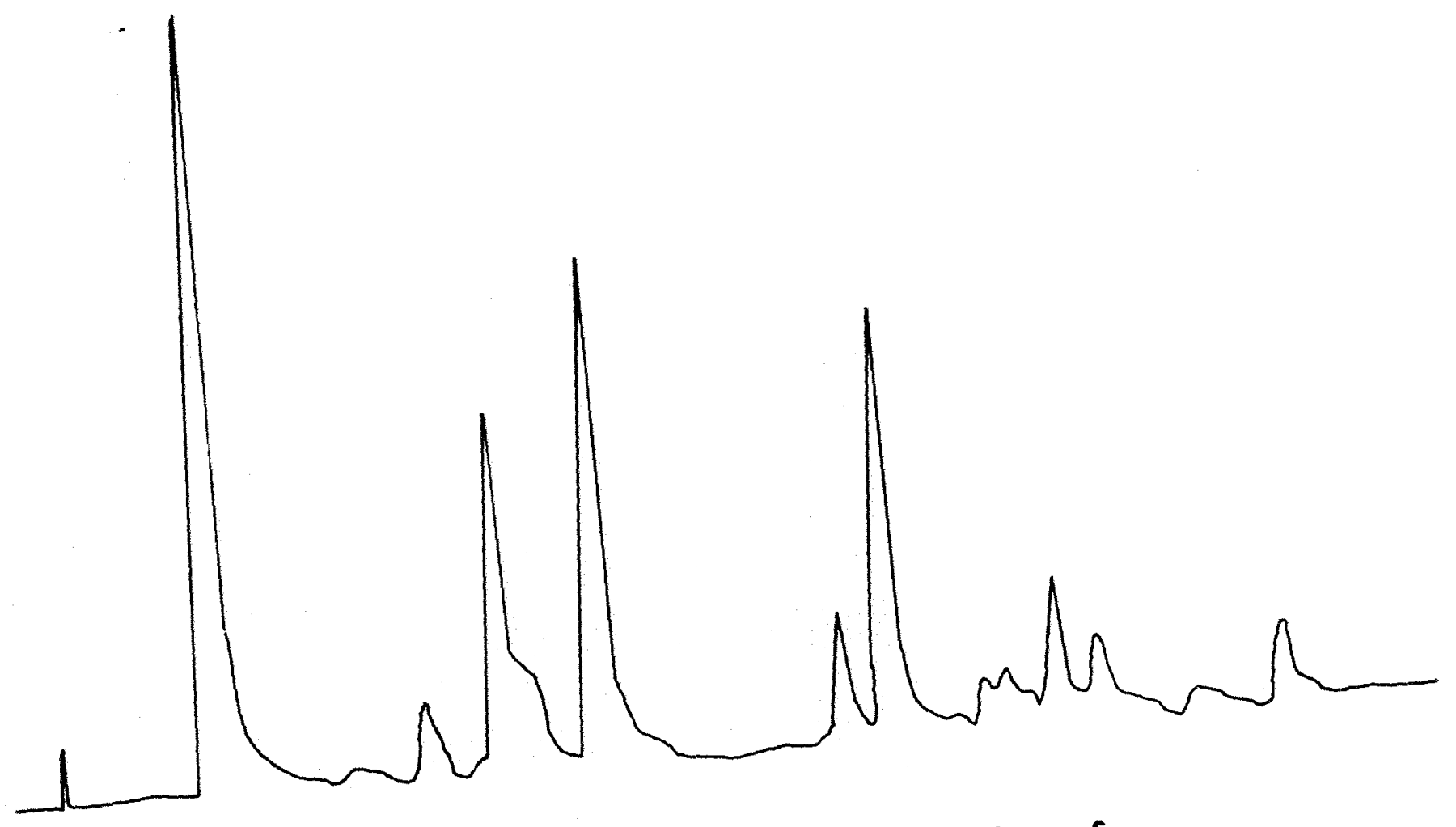

g. Cromatograma do tratamento com omissilo de enxofre

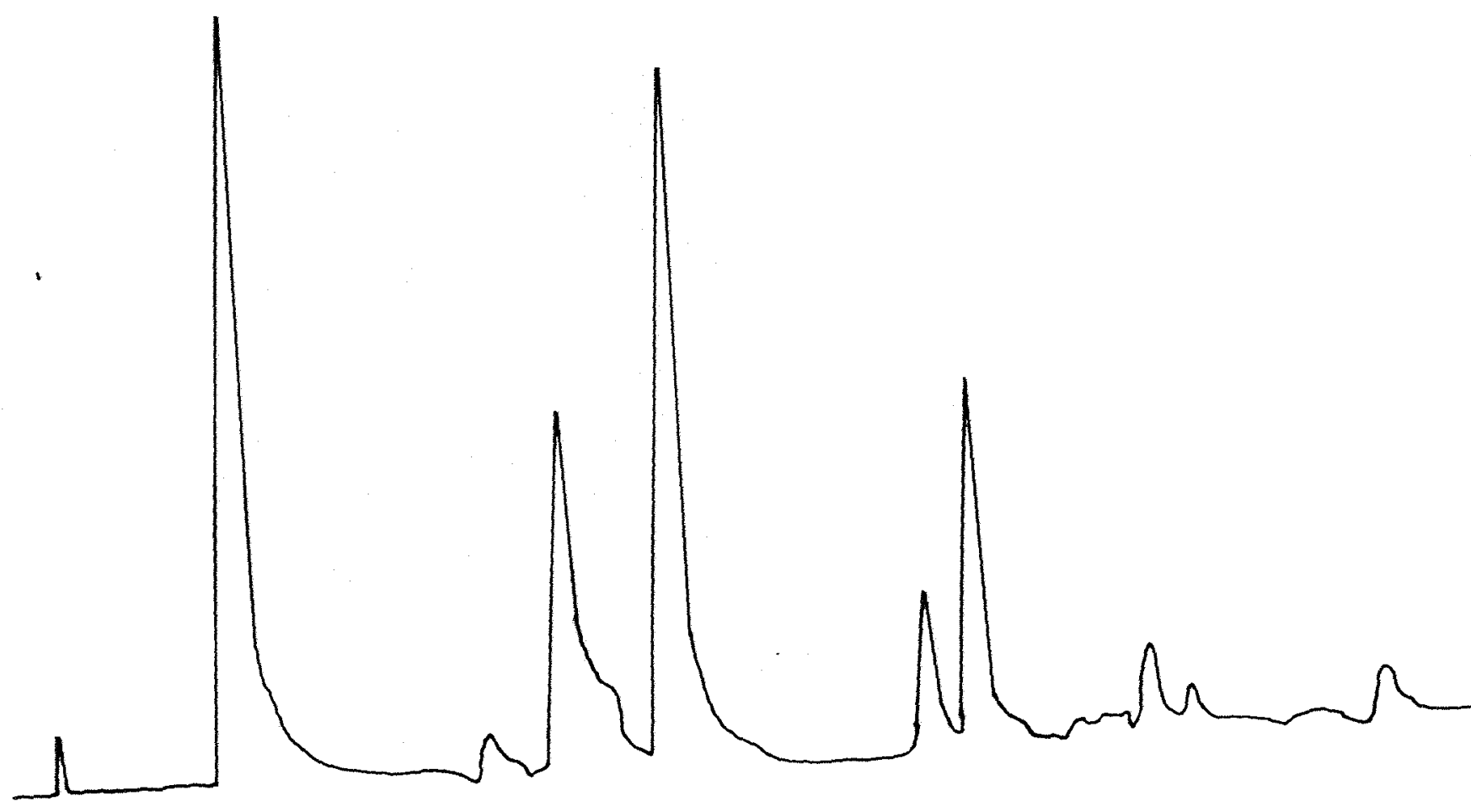

h. Cromatograma do tratamento com omissto do boro 
65

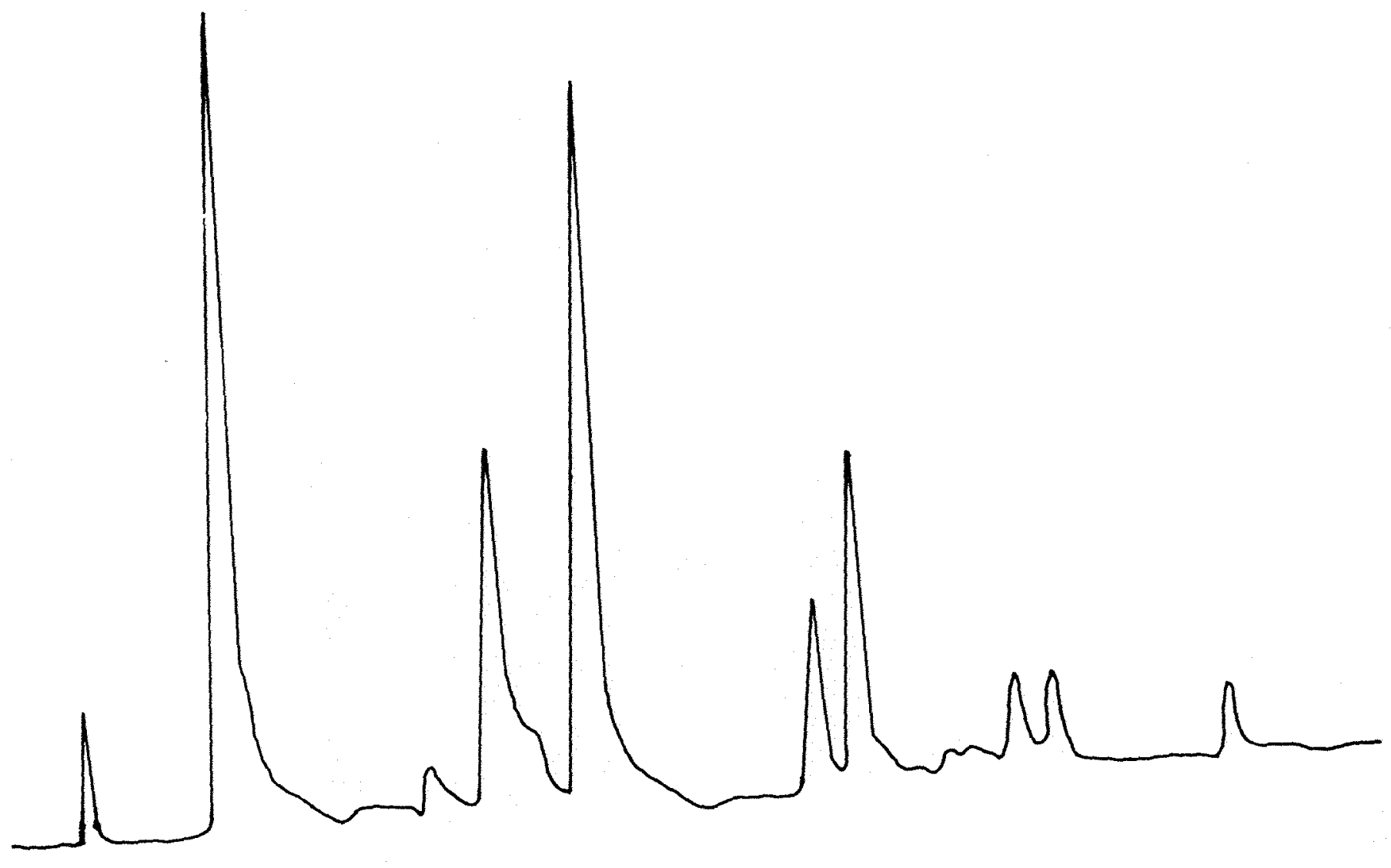

i. Cromatograma do tratamento com omissáo de zinco 